NBER WORKING PAPER SERIES

\title{
ANXIETY OR PAIN? THE IMPACT OF TARIFFS AND UNCERTAINTY ON CHINESE FIRMS IN THE TRADE WAR
}

\author{
Felipe Benguria \\ Jaerim Choi \\ Deborah L. Swenson \\ Mingzhi Xu \\ Working Paper 27920 \\ http://www.nber.org/papers/w27920 \\ NATIONAL BUREAU OF ECONOMIC RESEARCH \\ 1050 Massachusetts Avenue \\ Cambridge, MA 02138 \\ October 2020
}

We thank Sisi Zhang for outstanding research assistance. We thank JaeBin Ahn, Theresa Greaney, Jung Hur, Noh-Sun Kwark, Sang-Hyop Lee, SeungHoon Lee, Will Olney, E Young Song, Alan Spearot, Xiaojun Wang, and seminar participants at KERIC 2020, Sogang University, and the University of Hawaii. The views expressed herein are those of the authors and do not necessarily reflect the views of the National Bureau of Economic Research.

NBER working papers are circulated for discussion and comment purposes. They have not been peer-reviewed or been subject to the review by the NBER Board of Directors that accompanies official NBER publications.

(C) 2020 by Felipe Benguria, Jaerim Choi, Deborah L. Swenson, and Mingzhi Xu. All rights reserved. Short sections of text, not to exceed two paragraphs, may be quoted without explicit permission provided that full credit, including $\odot$ notice, is given to the source. 
Anxiety or Pain? The Impact of Tariffs and Uncertainty on Chinese Firms in the Trade War Felipe Benguria, Jaerim Choi, Deborah L. Swenson, and Mingzhi Xu

NBER Working Paper No. 27920

October 2020

JEL No. D81,F13,F14,F51

\begin{abstract}
$\underline{\text { ABSTRACT }}$
The unexpected outbreak of the U.S.-China trade war led to dramatic increases in the import and export tariffs confronting Chinese firms. Due to firm-level differences in trade engagement, customs trade data combined with tariff changes allow us to measure firm-level exposure to the trade war. Further, by adopting a new textual analysis approach to listed firms' annual reports, we develop trade policy uncertainty (TPU) measures that vary over firms and time. Our differencein-differences examination of these firm-level data reveals that trade war increases in U.S. tariffs and Chinese retaliatory tariffs both raised Chinese firms' TPU. The impact of tariffs on uncertainty is heterogeneous, and is most pronounced for smaller and less capital-intensive firms. This effect is also smaller for Chinese exporters that were more diversified in terms of partner countries. In the second stage of our analysis we explore and document the negative connection between Chinese firm-level increases in TPU and subsequent firm performance. Our estimates indicate that Chinese firms hit by a one standard deviation increase in TPU during the trade war reduced firm-level investment, R\&D expenditures, and profits by 1.4, 2.7, and 8.9 percent, respectively.
\end{abstract}

\author{
Felipe Benguria \\ Department of Economics \\ Gatton College of Business and Economics \\ University of Kentucky \\ $550 \mathrm{~S}$ Limestone \\ Lexington, KY 40513 \\ US \\ fbe225@uky.edu \\ Jaerim Choi \\ Department of Economics \\ University of Hawaii at Manoa \\ Saunders Hall 542 \\ 2424 Maile Way \\ Honolulu, HI 96822 \\ choijm@hawaii.edu
}

\author{
Deborah L. Swenson \\ Department of Economics \\ University of California, Davis \\ Davis, CA 95616 \\ and NBER \\ deswenson@ucdavis.edu
}

Mingzhi Xu

Science Building Building No. 1 Room 423N

Peking University

5th Yiheyuan Road

Haidian District

China

mingzhixu@nsd.pku.edu.cn

A data appendix is available at http://www.nber.org/data-appendix/w27920 


\section{Introduction}

Following the expression of multiple grievances and the completion of a 301 investigation into "China's laws, policies, practices, or actions that may be unreasonable or discriminatory and that may be harming American intellectual property rights, innovation, or technology development," on April 3, 2018 the U.S. announced its plan to levy 25\% tariffs on $\$ 50$ million of its imports from China. The very next day, China released its plan to retaliate against U.S. tariffs by setting $25 \%$ tariffs of its own on $\$ 50$ million of its imports from the U.S. As these threats were converted into action, and the U.S. and China exchanged in repeated rounds of protection and retaliation, new US tariffs imposed in the tariff rounds between July and September 2018 covered $\$ 250$ billion of Chinese exports to the U.S. Over the same time interval China's retaliatory tariffs targeted $\$ 110$ billion of imports from the U.S. ${ }^{1}$

The U.S.-China trade war, by rupturing and reversing decades of progress towards trade liberalization and by setting tariffs in a fashion that violated the rules and norms of WTO practice, dramatically raised the uncertainty facing economic agents (IMF, 2018). For this reason, timely evidence on the overall consequences of the trade war is greatly needed as a means of guiding future trade policies. Further, examining the trade war's effects provides a unique opportunity to understand the channels through which trade policy impacts the economy.

By assembling a unique and comprehensive dataset that links firm-level measures of tariff exposure and firm-level measures of trade policy uncertainty with a number of real outcomes for listed firms our paper provides the first accounting of the impact of the 2018-2019 trade war on Chinese firms. Construction of the tariff exposure measures combines firm-level customs data on trade in products with product-level trade war and MFN tariffs. Firm-specific measures of trade policy uncertainty are created through a textual analysis of firms' annual reports. These finely detailed data in tandem with a clean empirical strategy allows us to shed light on the mechanisms by which the trade war impacted firms.

We start by providing descriptive evidence showing trade policy uncertainty (TPU) spiked for most firms during the trade war period. We also use our firm-level TPU measures to construct an aggregate index, which notably maps closely the evolution of economy-wide TPU measures based on newspaper articles constructed by Davis et al. (2019).

Next, we demonstrate the connection between firm exposure to trade war tariff in-

\footnotetext{
${ }^{1}$ The value of U.S.-China trade affected by these actions is based on the approximate value of 2017 U.S exports and imports in the product categories targeted by the tariffs. This convention is used throughout the paper.
} 
creases and increases in firm-level TPU, quantifying the strength or the relationship by estimating regressions of firm-level TPU changes between 2017Q4 and 2018Q4 on changes in firm-specific tariff exposure via firm imports and exports. Note that U.S. and Chinese tariffs affect firms differently: U.S. tariffs reduce the demand for Chinese firms' exports, while Chinese tariffs make access to imported inputs more costly. We find that Chinese import tariffs elevated TPU: a ten percentage points increase in the Chinese tariff exposure measure is associated with a 0.157 standard deviation increase in trade policy uncertainty. Our results are robust to controlling for the region and industry fixed effects and the inclusion of lagged firm characteristics. This first key finding of our paper provides clear evidence that firms exposed to trade war tariffs experienced a trade policy uncertainty shock which operated particularly through tariffs that raised the cost of imported inputs.

We also investigate how heterogeneity in the association between tariffs on firm-level TPU across firms is related to firm characteristics and activities. First, we allow for an interaction between tariffs and lagged firm revenue, as a measure of firm size, and find that the effect of U.S. tariffs on TPU is larger among smaller firms. The impact of an increase in U.S. tariffs on TPU is 0.544 standard deviations lower as a firm's revenue doubles. Second, we also find that the impact of both U.S. and Chinese tariffs on firm-level TPU are larger among less capital-intensive firms. As a firm's capital stock doubles, the impact of an increase in U.S. (Chinese) tariffs on trade policy uncertainty is 0.443 (.864) standard deviations lower. Third, we ask whether firms with a wider range of export destinations and more extensive product variety, or more source countries and variety of imported products, exhibited smaller responses to rising tariffs. We find this to be the case generally, and particularly for exports. One additional country in a firm's export basket reduces the impact of U.S. tariffs on firm-level TPU by 0.028 standard deviations. We argue this reveals a real hedging channel since the diversification of export destinations reduces the impact of tariff shocks. ${ }^{2}$ Finally, we further investigate whether the ability to hedge in export markets could be hampered when firms have too much dependence on U.S. sales, given the fixed costs of locating and entering new markets. We find that the impact of U.S. tariffs on firm-level TPU is 1.274 standard deviations higher for U.S. dependent exporters compared to non-U.S. dependent exporters. Overall, these patterns provide novel evidence on the impact of external trade policy shocks on firm-level uncertainty.

In the second part of our paper, we analyze how increases in TPU affected real firm-

\footnotetext{
${ }^{2}$ The real hedging channel is consistent with previous work by Macedoni and $\mathrm{Xu}$ (2018), Caselli et al. (2020), and Kramarz et al. (2020). Caselli et al. (2020) note that international trade can lower economic volatility by allowing countries to diversify the sources of demand and supply across countries. Kramarz et al. (2020) find that most exporters' volatility is directly due to the lack of diversification in their portfolio of customers; using theory and empirical evidence, Macedoni and $\mathrm{Xu}$ (2018) show that trade elasticity is smaller for firms with more products.
} 
level performance and outcomes with a focus on magnitudes and timing. We find that increases in firm-level TPU reduce firm-level investment, $R \& D$ expenditures, and profits. A one standard deviation increase in TPU leads to a 1.44 percent decrease in investment contemporaneously. Compared with the initial period of 2017Q4, the effect of 2017Q4 - 2018Q4 TPU shock on firm-level investment cumulatively amounts to 2.04 percent in 2019Q3. A one standard deviation increase in TPU induces a decline in R\&D expenditures by 2.68 percent contemporaneously. While we do not detect a significant impact of 2017Q4 - 2018Q4 TPU change on firm profits at the same time horizon, we find that a one standard deviation increase in 2017Q4 - 2018Q4 TPU is associated with an overall decline in profits by 8.9 and 11.7 percent later on in 2019Q2 and Q3, suggesting that it takes time for profits to erode and give way to losses brought by rising trade policy uncertainty.

An important contribution of our paper is the dataset we assemble to investigate the underlying mechanisms. We measure outcomes based on quarterly and up-to-date data on Chinese listed firms. A key advantage of focusing on listed firms is timeliness. More representative data produced by the Chinese government becomes available with a lag of several years. ${ }^{3}$ In addition, we have compiled detailed product-level data on mostfavored-nation and additional trade war tariffs imposed by the U.S. and China on each other. We are able to assign exact measures of tariff exposure to each firm based not only on their broad industry but also based on customs transactions data. ${ }^{4}$

The most novel aspect of our dataset is the firm-level measure of trade policy uncertainty based on a textual analysis of firms' annual reports. We follow very recent work using the same approach to capture international firms' exposure and responses to Brexit (Hassan et al., 2020), and U.S. firms' exposure to political risk (Hassan et al., 2020, 2019) and the 2018-2019 trade war (Caldara et al., 2019).

The rest of the paper is organized as follows. Section 1.1 discusses the contribution of this paper to the existing literature. Section 2 summarizes the events in the ongoing trade war. Section 3 describes the various data sources employed. Section 4 analyzes the impact of trade war tariffs on firm-level trade policy uncertainty. Section 5 then studies

\footnotetext{
${ }^{3} \mathrm{~A}$ second advantage from data on listed firms is its reliability. Chen et al. (2019) explain how local governments adjust data reported in official firm-level surveys (which underlie GDP calculations) to meet the goals imposed by the central government. Data reported on listed firms should be much more reliable as these firms face more scrutiny. The main limitation of the sample is its coverage. Listed firms are just a fraction of all firms, are larger on average, and are not representative of the entire firm distribution. Given the concentration of economic activity, however, these firms account for a large share of macroeconomic aggregates. We argue that sacrificing coverage in favor of timeliness is worthwhile, especially in the current context of very limited available empirical work on the impact of these previously unseen policies. Previous work studying the effects of trade policies or trade shocks using data on listed firms includes Bloom et al. (2019); Hombert and Matray (2018); Guadalupe and Wulf (2010); Autor et al. (2020); Keller and Yeaple (2009) and Benguria (2019) among others.

${ }^{4}$ The most recent customs data available is the year 2016, so we are not able at this point to analyze firm-level trade flows as outcomes.
} 
the effect of firm-level TPU on economic outcomes. Section 6 concludes.

\subsection{Contribution to the Literature}

This paper joins a nascent literature evaluating the consequences of the U.S.-China trade war, and is, to the best of our knowledge, the first to examine the impact of the trade war on real economic outcomes for Chinese firms in particular and the Chinese economy in general. The literature to date has made strides quantifying the effects on the U.S. economy. Specifically, Fajgelbaum et al. (2019) and Amiti et al. (2019) quantify the combined effect of the tariffs applied by the U.S. on China and other trade partners, and these countries' retaliatory tariffs; the results indicate that the U.S. has suffered a welfare loss equal to about $0.04 \%$ of GDP. Subsequent work by Amiti et al. (2020) demonstrates the investment consequences for U.S. listed firms. Turning to evidence from financial markets, analysis of U.S. and Chinese firm stock price reactions by Huang et al. (2018) finds that the March 2018 announcement of the investigation that led to the first round of U.S. tariffs on China led to a substantial drop in stock market returns for Chinese exporters around the announcement date.

This paper also adds to a new strand of work in the literature which leverages novel empirical methods to measure the impact of uncertainty on firms. Pioneering work by Hassan et al. (2019) analyzes earnings call reports to construct measures of politicallyrelated risk as a count of the share of time in earnings calls reports devoted to discussion of political risk. Closer to our paper, Caldara et al. (2019) analyze the effect of trade policy uncertainty on investment by U.S- listed firms. Their measure of firm-level trade policy uncertainty, which is based on earnings calls reports, is constructed by counting the share of instances in which trade-policy related words appear together with uncertaintyrelated terms. Using this measure, they document a negative impact of firm-level TPU on investment over the 2015Q1-2018Q4 period. In addition, they show that firms in industries facing new U.S. import tariffs during the trade war further reduce their investment. Steinberg (2020)'s comment on Caldara et al. (2019) suggests new exercises that we implement in this paper. Specifically, we use firm-level measures of tariff exposure and link them to firm-level TPU, thereby unpacking the sources of firm-level TPU. ${ }^{5}$

Our work complements a broader literature on the economic consequences of trade policy uncertainty (or economic uncertainty in general). A set of papers has used the uncertainty surrounding U.S. tariff preferences towards China around China's W.T.O. entry (Handley and Limão, 2017; Pierce and Schott, 2016; Feng et al., 2017). An alternative ap-

\footnotetext{
${ }^{5}$ Handley and $\mathrm{Li}$ (2018) construct time-varying measure of firm-specific idiosyncratic uncertainty from analyzing the text of company reports filed with the U.S. Securities and Exchange Commission. However, our focus is the trade policy uncertainty that is in line with Caldara et al. (2019).
} 
proach for capturing the consequences of trade policy uncertainty turns instead to the estimation of structural models (Steinberg, 2019). ${ }^{6}$ Alessandria et al. (2019) use within year timing of TPU prior to China's WTO accession to quantify TPU, and our work allows us to identify the timing of TPU effects, including the short- to medium-run changes. ${ }^{7}$

This paper also contributes to a literature that has studied the impact of trade policies or trade shocks on Chinese firms. Brandt et al. (2017) dissects the channels through which China's entry into the W.T.O. led to productivity improvements among Chinese firms, while $\mathrm{Lu}$ and $\mathrm{Yu}$ (2015) document how this episode led to a reduction in markup dispersion across firms. Khandelwal et al. (2013) study the response of Chinese exporters in the textile and apparel sector to the removal of quotas in destination markets and how this response is mediated by the allocation of quotas.

\section{The U.S.-China Trade War}

The recent U.S. trade policy actions of the Trump administration have imposed new tariffs on named partners. These actions, which have been justified by a wide range of arguments stand in stark contrast with the long previous trend towards freer trade. The first trade barriers imposed early in the Trump administration were global safeguard tariffs on imports of washing machines and solar panels in January 2018 and tariffs on steel and aluminum imports in March 2018, rationalized by an argument of threats to national security. These tariffs were focused on a few industries, were not specific to China, and led to retaliatory tariff action by a number of U.S. trading partners.

Soon afterwards, Trump administration trade policy actions focused on Chinese trade. In particular, following the March 2018 conclusion of a 301 investigation into China's laws or actions that may lead to discriminatory treatment of intellectual property rights held by U.S. companies, the U.S. imposed a broad round of tariffs on Chinese products. China immediately met this change in U.S. policy with retaliatory tariffs applied to its imports from the U.S. The ensuing escalation of protection rendered by the U.S.-China trade war through 2018 and 2019 raised tariffs dramatically, and has given rise to first order concerns and challenges for the global economy. In total, U.S. tariffs on Chinese products cover a list representing $\$ 250$ billion (in terms of their 2017 value), which is about half the imports from China in 2017. Chinese tariffs apply to a list of products representing about $85 \%$ of U.S. exports to China in 2017. Here we briefly describe the main, broad tariff rounds

\footnotetext{
${ }^{6}$ Additional work in this literature includes Handley (2014); Handley and Limao (2015); Handley and Limão (2017); Carballo et al. (2018); Graziano et al. (2018).

${ }^{7}$ The findings of our paper are consistent with Benguria and Saffie (2019) who study US exports to China during the trade war and find support for a trade policy uncertainty channel, given that exports fall relatively more in sectors facing a larger risk of tariff increases.
} 
imposed by the U.S. and China upon each other. ${ }^{8}$

The first round of tariff penalties imposed by the U.S. covered $\$ 50$ billion in imports and was rolled out in two rounds which levied new $25 \%$ tariffs on all covered products. The first wave launched in July 2018 covered 818 HS 8-digit products which were tied to $\$ 34$ billion of U.S. imports while the second tariff wave in August 2018 wave targeted 279 HS 8-digit products involving $\$ 16$ billion in U.S. imports. China's first round of retaliatory tariffs also covered $\$ 50$ billion in imports from the U.S. In parallel with U.S. actions, their new 25\% tariffs were implemented in July and August waves covering \$34 billion and $\$ 16$ billion and targeting 545 and 333 HS 8-digit products respectively. ${ }^{9}$ The second U.S. tariff round, imposed in September 2018, applied a 10\% tariff to 6,056 HS 8-digit products covering \$200 billion in imports. China unleashed its second round of tariffs in tandem with the U.S. actions, imposing new 5\% and 10\% rates in September 2018 on 5,207 HS 8-digit products comprising $\$ 60$ billion of China's imports. ${ }^{10}$

In December 2018 the U.S. announced its intention to levy further tariffs on $\$ 200$ billion of its imports from China. This new round included a future elevation of tariffs to $25 \%$ on the products the U.S. had just set 10\% tariffs against. As before, China responded immediately with its intention to also increase its tariff charges. However, the December 2018 meeting of the U.S. and Chinese presidents culminated in a truce that postponed the increase in the rates on the products targeted by the U.S. $\$ 200$ billion round and China's retaliatory round. In January 2019, China eliminated retaliatory tariffs on cars and car parts and unilaterally reduced some of its MFN tariffs.

Finally, in May 2019, the U.S. decided to raise its ad-valorem tariff rates on the product list of the $\$ 200$ billion round from $10 \%$ to $25 \%$. In June 2019, in response to the tariff hike, China also raised its tariff rates on the product list that was already targeted in September 2018 , covering $\$ 36$ billion.

The sequence of tariffs unleashed through the U.S.-China trade war generated high levels of uncertainty, as firms were forced to re-evaluate their sourcing and production strategies. As Amiti et al. (2019) argue, the U.S.-China trade war was a surprising, unanticipated event for firms given that Trump's election was not predicted by the polls. In addition, while there was a discussion on revising trade policy during the presidential campaign, there were no early announcements on which industries would be targeted by tariffs.

\footnotetext{
${ }^{8}$ Bown and Kolb (2019) provide a detailed timeline to the U.S. - China trade war.

${ }^{9}$ In April 2018, China also imposed tariffs on a small set of products covering \$2.4 billion in imports from the U.S. in response to the U.S. steel and aluminum tariffs. This tariff round applied 15\% and $25 \%$ ad-valorem rates against 91 HS 6-digit (104 HS 8-digit) products.

${ }^{10}$ This second Chinese round was announced as a $\$ 60$ billion round but in practice covered $\$ 52$ billion in imports from the U.S.
} 


\section{Data Sources and Firm-level Measurement}

\subsection{Firm-level Data}

We use firm-level data from three sources. The first is the China Customs Dataset (20132016), which provides export and import values at the firm-product-country-year level for all international transactions from China. We define a product as a Harmonized System (HS) eight-digit code.

Second, to construct the firm-level uncertainty measure, we use transcripts of the annual reports from 2008 to 2018 released by Chinese firms that were listed in Shanghai and Shenzhen Stock Exchange's domestic A share markets. The reports were scraped from East Money Information (i.e., a financial data provider in China) in PDF format, and converted into text. ${ }^{11}$ Our paper is the first to provide this form of textual analysis for Chinese firms.

Third, to better understand the effects of the U.S.-China trade war on firm performance, we use firm-level data reported by COMPUSTAT Global which tracks firm performance for 2,312 Chinese firms on a quarterly basis. This data is limited to firms listed on the stock market. Focusing on listed firms provides the advantage of timeliness; other firm-level data sources are released with a lag of several years. The data we use from this source run from 2016Q1 to 2019Q3. However, when we link the COMPUSTAT Global data with our annual firm-level uncertainty measure, we use two data points (i.e., 2017Q4 and 2018Q4) for our benchmark analysis. The COMPUSTAT variables we use are quarterly measures of firm revenue, capital stock, and profits. We also utilize the data on R\&D expenditure which is only available on an annual basis.

\subsection{Tariff Data}

We compile a detailed dataset of U.S. tariffs imposed upon China and Chinese retaliatory tariffs on the U.S. We complement this with U.S. and Chinese MFN tariffs. We follow Fajgelbaum et al. (2019) in the construction of our dataset, extending it forward in time.

The data sources for U.S. trade war tariffs are official communications by the U.S. Trade Representative, Fajgelbaum et al. (2019) and the Li (2018) trade war tariff dataset. We obtain U.S. MFN tariffs from the WTO (World Trade Organization) Tariff Download Facility database.

\footnotetext{
${ }^{11}$ The annual reports document each public company's activities, including the names of key staff, what they did and why in the financial year. These reports disclose each firm's main financial data, information on operational performance, as well as future ventures and plans. The Accounting Standard for Business Enterprise promulgated by the Ministry of Finance of China requires that all Chinese firms use December 31 as the end date for the financial year.
} 
The data sources for Chinese trade war tariffs are Fajgelbaum et al. (2019), the Li (2018) trade war tariff dataset and Bown and Kolb (2019). Note that Chinese MFN tariffs from the WTO Tariff Download Facility database are complemented by Bown and Kolb (2019) who compile recent and frequent changes in Chinese tariffs observed during 2018 and 2019 from official Chinese government communications.

Figure 1: The Average U.S. and Chinese Tariff

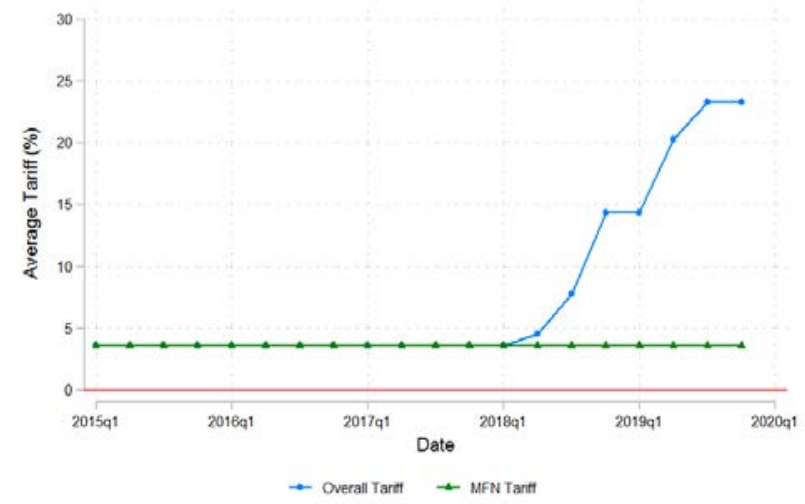

(a) U.S. Tariff on Chinese Goods

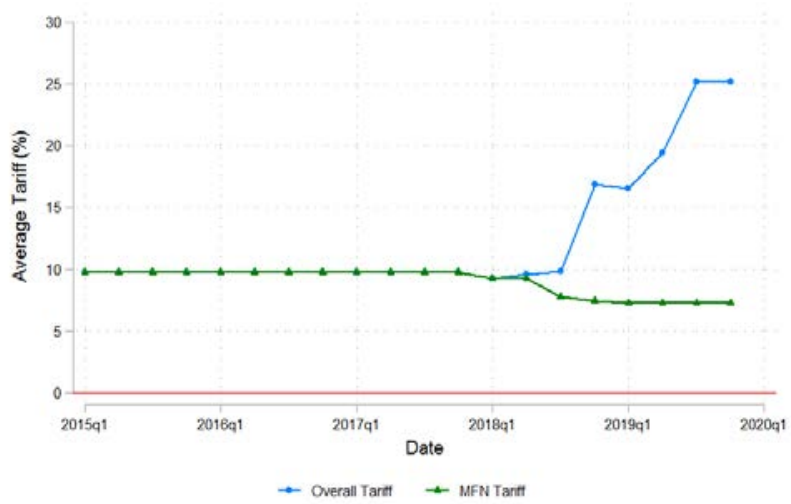

(b) Chinese Tariff on U.S. Goods

Notes: The average tariff is the simple arithmetic average of HS 10-digit tariffs. The green line denotes MFN tariffs and the blue line denotes overall tariffs (MFN plus trade war tariffs).

Table 1: Summary Statistics: Matched Chinese Firms in COMPUSTAT Global

\begin{tabular}{lcr}
\hline \hline \multicolumn{1}{c}{ Variable } & Mean & Standard Deviation \\
\hline \multicolumn{3}{c}{ Average Firm Exports $(2013-2016)$} \\
Number of Unique Matched Firms & 1,601 & - \\
Number of Observations & 5,127 & - \\
Number of Products & 22.400 & 61.601 \\
Number of Countries & 24.988 & 26.121 \\
Exports (million USD) & 60.148 & 213.655 \\
Share of Exports to the US & $12.22 \%$ & $21.43 \%$ \\
\hline \multicolumn{3}{c}{ Average Firm Imports (2013-2016) } \\
Number of Unique Matched Firms & 1,611 & - \\
Number of Observations & 4,925 & - \\
Number of Products & 20.972 & 37.877 \\
Number of Countries & 7.195 & 7.164 \\
Imports (million USD) & 39.914 & 223.874 \\
Share of Imports from the US & $13.22 \%$ & $25.87 \%$ \\
\hline \hline
\end{tabular}

Notes: The table summarizes firm-year-level exports and imports for the matched listed enterprise during 2013 and 2016 (pooling firms together). Each product is defined by the unique HS 8-digit code. 
Figure 1 displays the evolution of tariffs imposed by the U.S. (panel (a)) and China (panel (b)), respectively, where each dot denotes the average tariff computed as the simple mean of tariffs across all HS 10-digit sectors. ${ }^{12}$ As shown in Figure 1, the average tariff faced by China in the U.S. was essentially constant up to the second quarter of 2018, at about $4.1 \%$. Starting from the third quarter of the same year, the average U.S. tariff on Chinese goods increases from $7.0 \%$ to $20.3 \%$ in the fourth quarter of 2019. For comparison, the average MFN tariff (in green in the same graph) remains constant over time at about 3.6\%. Average Chinese tariffs on US exports increased slightly following the April 2018 round of retaliation in response to US steel and aluminum tariffs. Later that year, China imposed a $\$ 50$ billion round in July-August a and a $\$ 60$ billion round in September. The figure also reflects the removal of retaliatory tariffs on cars and car parts in January 2019 and the extension in tariff rates on some of the products in the earlier $\$ 60$ billion round occurring in June 2019.

A similar tariff change is found for the tariff imposed by China; that is, the tariff remains at its low level of $9.0 \%$ up to the third quarter of 2018, after which the tariff increases from $15.3 \%$ in the fourth quarter of 2018 to $22.0 \%$ in the fourth quarter of 2019 . The figure reflects the imposition of tariffs on steel and aluminum in the first quarter of 2018, followed by broad tariff rounds (covering $\$ 50$ and $\$ 200$ billion in imports) between July and September 2019. In addition, it shows the increase in tariff rates in the products covered by the $\$ 200$ billion round in May 2019 .

To relate firm performance to trade policy uncertainty and the tariff exposure measures, we first translate firm names in COMPUSTAT Global into Chinese, and refine the sample to listed firms from the Shanghai and Shenzhen Stock Exchange's domestic A share markets (for which we have annual reports). Then we use firm names to match exactly the firms in COMPUSTAT Global to those in China customs to track their previous activities in the global market. ${ }^{13}$ Table 1 reports the summary statistics on average exports and imports for the matched Chinese listed firms in COMPUSTAT Global. Appendix Table A.4 reports similar statistics for matched Chinese listed firms by year. Figure 2 displays the variation in the number of firms across Chinese cities, and we use darker colors to denote a greater number of firms. According to the map, the matched sample is geographically representative overall, covering large geographic areas within China with coastal regions hosting more firms than other areas.

\footnotetext{
${ }^{12}$ The detailed numbers are provided in Appendix Table A.1. The weighted average of both U.S. and Chinese tariffs can be found in Appendix Figure E.1.

${ }^{13}$ Specifically, we first identify the firms whose names are identical in both samples. For the unmatched firms in COMPUSTAT Global, we employ the fuzzy match technique powered by Stata: for each of the unmatched firm in COMPUSTAT Global, we use the code "matchit" and set the cutoff similarity score as 0.65 to identify a wide range of possible firm names in customs; we then manually exclude false matches.
} 


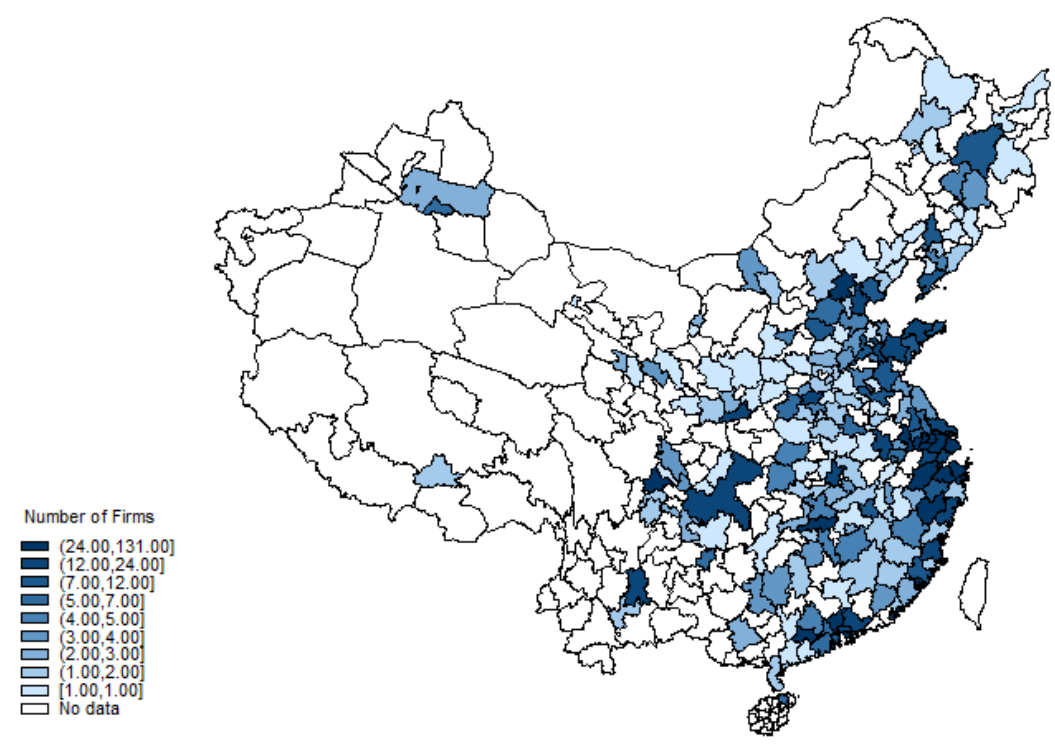

Notes: The information on city location of matched firms is from Chinese customs data, where a city is defined by a unique 4-digit region code.

Figure 3 provides information on the patterns of firm exports and imports in the preperiod before the U.S.-China trade war. As displayed in panel (a), we observe that firms with larger values of total exports also had larger shares of sales to the U.S. market. This association emerges whether we pool the samples or use the average over the years 2013 to $2016 .{ }^{14}$ While firms selling more in the global market are also likely to import larger amount of goods (panel (b)), there is no systematic pattern suggesting that firm exports positively depend on firm imports from the United States, as the coefficient remains insignificant in panel (c).

\subsection{Firm-level Tariff Exposure Measures}

Provided with tariffs and customs data, we are able to create time-varying measures of a given firm's import and export tariff exposure. Tariff ${ }_{i t}^{\text {U.S. }}$ measures the U.S. tariff exposure

\footnotetext{
${ }^{14}$ For example, the $t$-statistics for the coefficient obtained by regressing $\ln$ (Firm Exports) on the share of exports to the U.S. is 4.91 in the pooled sample, and is strongly significant. In contrast, as displayed in Appendix Figure E.2, imports display the opposite pattern: firms that import more have a smaller share of imports from the U.S.
} 
Figure 3: Firm Exports, Imports and the U.S. Shares for the Matched Listed Firms

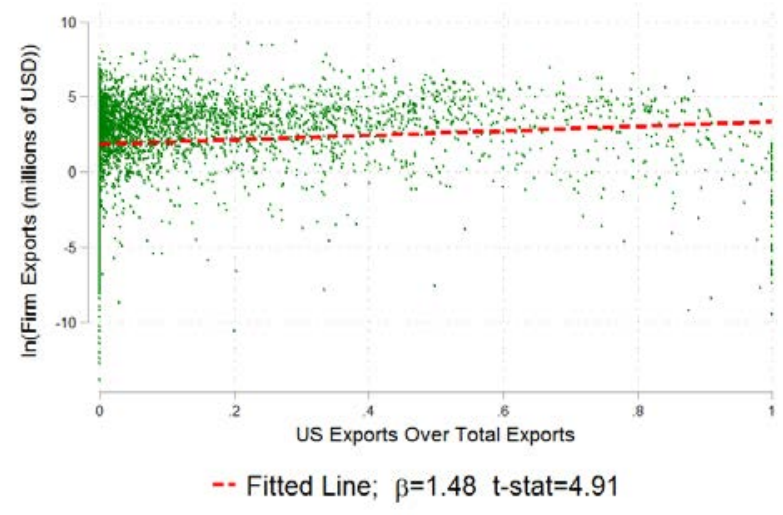

(a) Exports and the U.S. Export Share

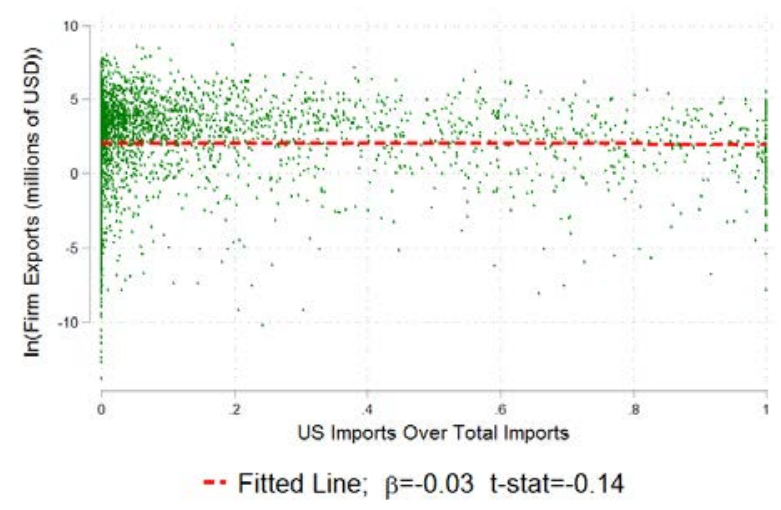

(c) Exports and the U.S. Import Share

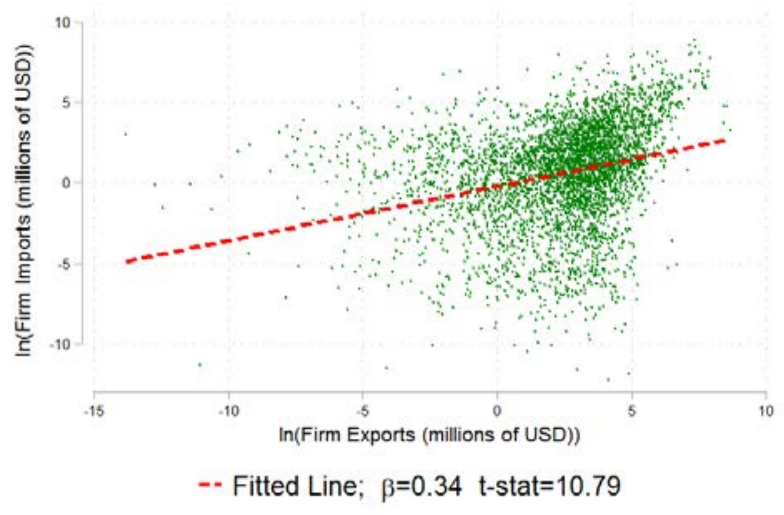

(b) Exports and Imports

Notes: The scatter plots use customs data for the matched firms for all years between 2013 and 2016. Panel (a) displays the correlation between firm total exports and the share of exports to the United States; panel (b) reports the correlation between firm imports and exports; panel (c) plots firms' total exports and the share of imports sourced from the United States. 
of Chinese firm $i$ at time (i.e., quarter) $t$, which is constructed as follows,

$$
\operatorname{Tariff}_{i t}^{\mathrm{U} . S .}=\sum_{j \in J_{i}^{e}}\left[\frac{X_{i j 0}^{\mathrm{U.S}}}{\sum_{s \in J_{i}^{e}} X_{i s 0}^{\mathrm{USO}}} \tau_{j t}^{\text {U.S. }}\right]
$$

where $\tau_{j t}^{\text {U.S. }}$ is good $j^{\prime}$ s ad valorem tariff (i.e., MFN tariff plus trade war tariff) imposed by the U.S. at time $t, X_{i j 0}^{\text {U.S. }}$ is average exports of good $j$ to the U.S. by firm $i$ during 2013-2016, and $J_{i}^{e}$ is the set of goods produced by firm $i$. Following Topalova and Khandelwal (2011) and Rodriguez-Lopez and Yu (2017), we hold export value weights for each good fixed at the initial period value to avoid potential reverse causality in firm's exports with respect to U.S. tariffs. Ad-valorem tariffs are weighted by the share of each product in each firm's total exports. Likewise, based on China's retaliatory tariffs on U.S. goods and firm import data, we construct firm $i$ 's Chinese tariff exposure in time $t$ as follows:

$$
\operatorname{Tariff}_{i t}^{\mathrm{CHN}}=\sum_{j \in J_{i}^{m}}\left[\frac{M_{i j 0}^{\mathrm{U.S} .}}{\sum_{s \in J_{i}^{m}} M_{i s 0}^{\mathrm{USS}}} \tau_{j t}^{\mathrm{CHN}}\right]
$$

where $\tau_{j t}^{\mathrm{CHN}}$ is good $j$ 's tariff imposed by China on U.S. goods at time $t, M_{i j 0}^{\mathrm{U} . S .}$ is the average import value of good $j$ from the U.S. by firm $i$ during 2013-2016, and $J_{i}^{m}$ is the set of goods imported by firm $i$. Here too, we use time-invariant weights computed in the initial period to avoid potential changes in weights driven by tariff changes.

Figure 4 displays the mean and standard deviation of the firm-level export and import tariff exposure measures within each quarter. Panel (a) corresponds to the tariff imposed

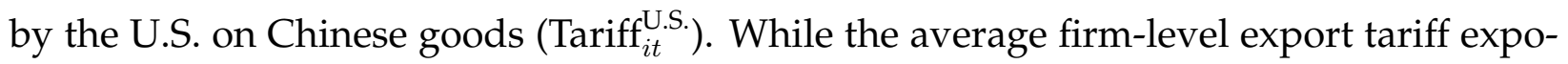
sure starts to increase after the second quarter of 2018 (from 2.3 percent in 2018-Q1 to 3.0 percent in 2018-Q2), a substantial increase takes place in the third quarter of 2018, which also exhibits large heterogeneity across firms. Panel (b) reports the firm-level import tariff exposure based on Chinese retaliatory tariffs on U.S. goods (Tariff ${ }_{i t}^{\mathrm{CHN}}$ ). The average import tariff exposure started to rise in the fourth quarter of 2018, a quarter later than the export tariff change (from 6 percent in 2018-Q3 to 12.7 percent in 2018-Q4). ${ }^{15}$ Appendix Table A.2 provides more details about the most affected SIC 3-digit industries as indicated by the two tariff exposure measures for Chinese listed firms. According to panel (I), U.S. trade war tariffs most heavily affected China's sectors related to industrial and commercial machinery \& computer equipment, electronic equipment, and transportation equipment, for which the average firm-level Tariff ${ }_{i t}^{\mathrm{US}}$. By the end of 2019 the average tariff

\footnotetext{
${ }^{15}$ Appendix Table A.5 provides more detailed statistics on the time pattern of tariff exposure changes. We also report the change in the export and import tariff exposure measures for Chinese firms in Appendix Figure E.3, which shows a similar pattern as that observed in Figure 4.
} 
facing the firms in our sample had risen by 23.4 percentage points above the low average rate of 2.2 percent between 2013 and 2016. In contrast, in panel (II), tariff exposure due to China's retaliatory tariffs had the strongest effects in light-manufacturing sectors such as food \& kindred products, furniture, and fabricated metal products. By the end of 2019, the average firm Tariff ${ }_{i t}^{\mathrm{CHN}}$ had risen13.4 percentage above the initial tariff average of 5.9 percent between 2013 and 2016.

Figure 4: Import and Export Tariff Exposures of Chinese Listed Firms

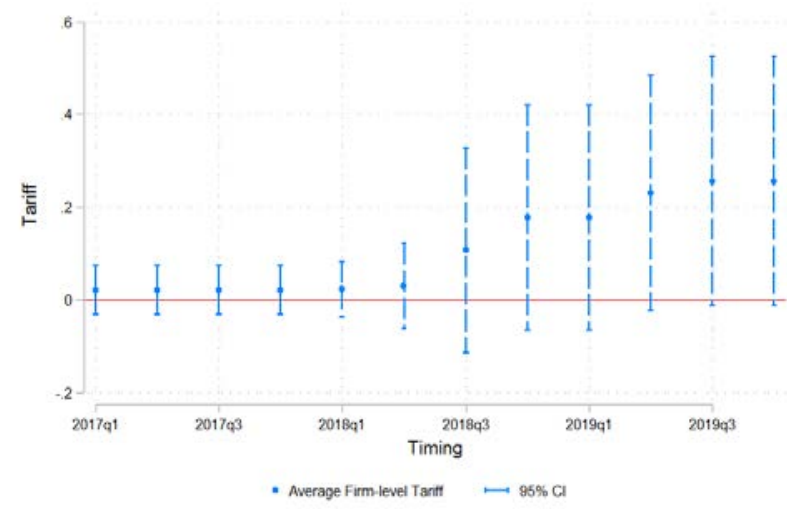

(a) U.S. Tariff on Chinese Goods

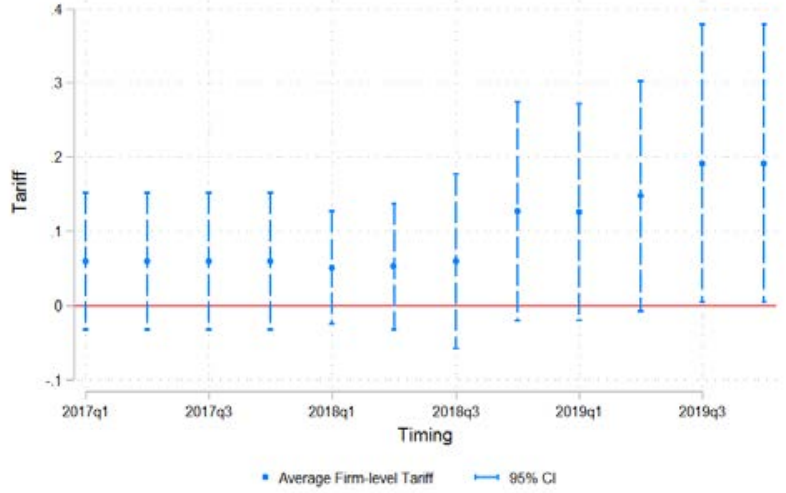

(b) Chinese Tariff on U.S. Goods

In Figure 5 we show how firm-level tariff exposure depended on firm-level export and import activities in the pre-period (2013-2016). In panel (a), firms with bigger total exports are more likely to have a larger values of Tariff U.S. . However, we do not find a systematic pattern between U.S. exports or export reliance on the U.S. market (i.e., the share of exports to the U.S.) and Tariff U.S. as displayed in panels (b) and (c), respectively. On the import side (Figure 6), Tariff ${ }_{i t}^{\mathrm{CHN}}$ is not correlated with firm overall imports. Instead, as displayed in panel (b), a firm's imports from the U.S. were positively related to Tariff ${ }_{i t}^{\mathrm{CHN}}$, though the positive correlation becomes weaker when we look at import reliance on the U.S. market in panel (c).

The summary figures and tables in this section imply that firm's exports to the United States are correlated with firm size. Since the selection of firms into the U.S. market may lead to an endogeneity issue, when we estimate the impact of tariff exposure on firmlevel trade policy uncertainty and other firm-level outcomes, and we address this issue by checking for pre-existing trends.

\subsection{Firm-level Trade Policy Uncertainty Measure}

To construct a firm-level time-varying measure of trade policy uncertainty (TPU), we employ textual analysis of transcripts of annual reports released by Chinese listed firms for 
Figure 5: Pre-period Export Characteristics and the Export Tariff Exposure Measure Tariff $i t$.S.

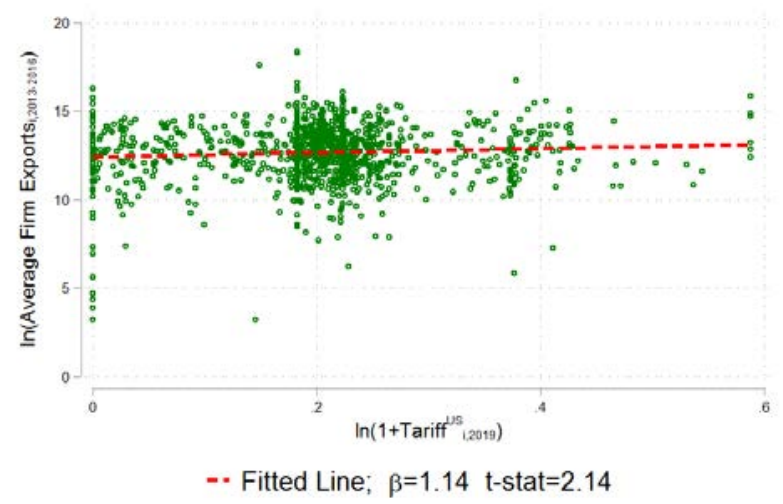

(a) Firm Exports

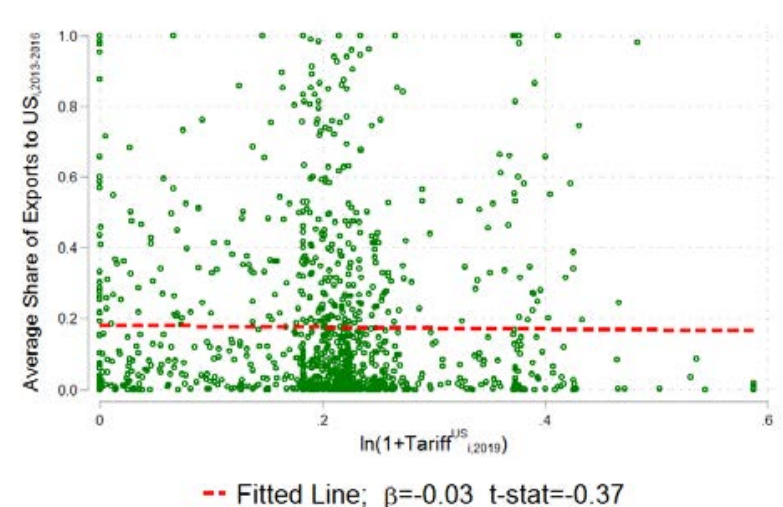

(c) Share of Exports to the United States

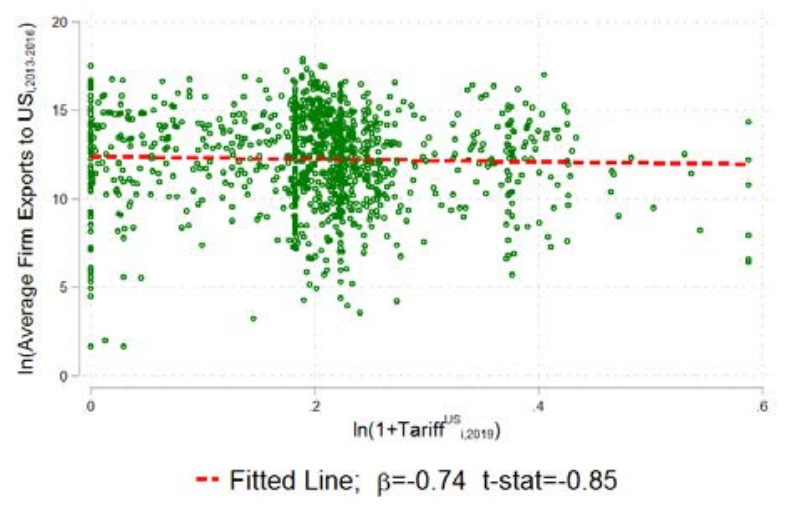

(b) Firm Exports to the United States 
Figure 6: Pre-period Import Characteristics and the Import Tariff Exposure Measure Tariff $_{i t}^{\mathrm{CHN}}$

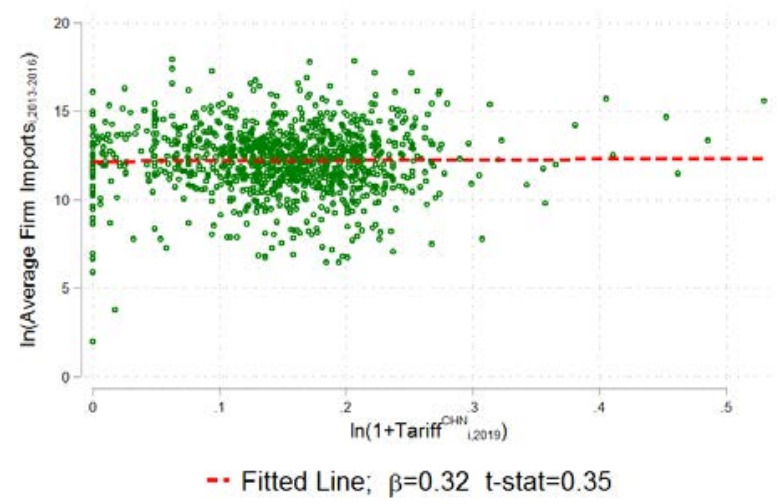

(a) Firm Imports

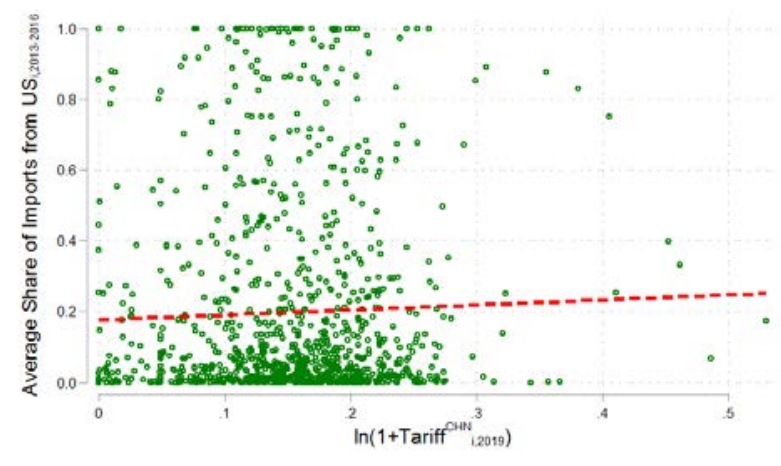

- Fitted Line; $\beta=0.14$ t-stat $=1.20$

(c) Share of Imports from the United States

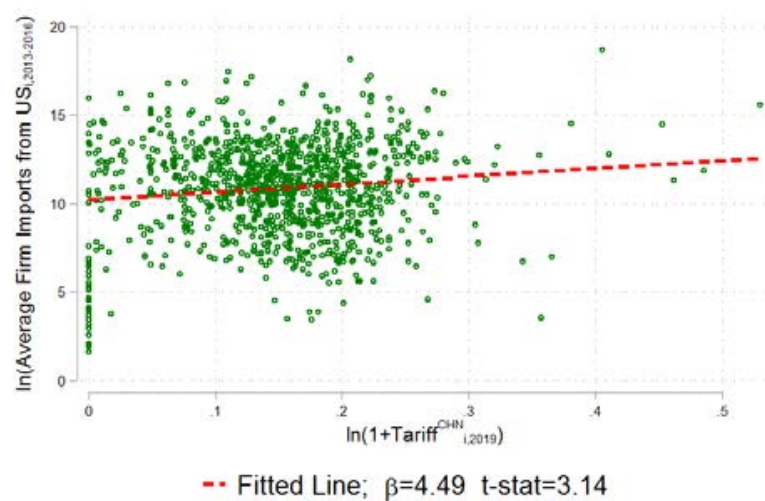

(b) Firm Imports from the United States 
each year between 2008 and 2018, following the method of Caldara et al. (2019). We collect all reports filed by companies listed in the Shanghai and Shenzhen Stock Exchange's domestic A share markets. Annual reports document public companies' activities, including the names of key staff, what the companies did and why in each financial year, main financial indicators and operational performance measures, as well as information about future ventures and plans. ${ }^{16}$

The reports are scraped from East Money Information (a financial data provider in China) in PDF format. We then convert the reports to text and translate the firm names in English (as reported in COMPUSTAT Global) to Chinese, so we can manually match them to the listed firms which have annual reports. Appendix Table A.3 summarizes the number of firms in COMPUSTAT Global that are matched to their annual reports. As annual reports are only available for listed firms in China (i.e., Shanghai and Shenzhen Stock A share markets only), we are not able to find reports for firms that are listed in other regions such as Taiwan, Singapore or the U.S. We are able to match about 2,400 Chinese Compustat firms (out of 2,505). ${ }^{17}$

Construction Method Our annual firm-level trade policy uncertainty measures are constructed using a textual analysis of the transcripts of yearly reports of publicly listed companies in China. The construction method is similar to Caldara et al. (2019), and consists of three steps. ${ }^{18}$

Table 2: The List of Keywords

\begin{tabular}{cl}
\hline \hline Keywords Type & \multicolumn{1}{c}{ Keywords } \\
\hline Trade policy & $\begin{array}{l}\text { international trade (mao4yi4, jing1mao4, zi4mao4, shi4mao4), export (chu1kou3), } \\
\text { import (jin4kou3), tariff (guan1shui4), barriers (bi4lei3), anti-dumping (fan3qing1xiao1), } \\
\text { outsourcing (wai4bao1), protectionism (bao3hu4zhu3yi4), unilateralism (dan1bian1zhu3yi4) }\end{array}$ \\
Uncertainty & $\begin{array}{l}\text { uncertainty (bu4que4ding4, bu4ming4que4), unclear (bu4ming4lang3, wei4ming2), } \\
\text { unexpected (nan2liao4, nan2yi3gu1ji4, nan2yi3yu4ji4, nan2yi3yu4ce4, nan2yi3yu4liao4), } \\
\text { risks (feng1xian3, wei1xian3), crisis (wei1ji1), threat (wei1xie2), unknown (wei4zhi1) }\end{array}$
\end{tabular}

Notes: Chinese pinyin for each keyword is displayed in the bracket.

\footnotetext{
${ }^{16}$ The Accounting Standard for Business Enterprises promulgated by the Ministry of Finance of China requires that all Chinese firms use December 31 as the same end date of the financial year. Detailed information on Chinese accounting standards and rules on information disclosure are provided in Appendix B.

${ }^{17}$ Appendix Figure E.4 displays an example of an annual report for Angang Steel Company (which has a COMPUSTAT GVKEY 205808). The figure only exhibits the initial page of the 2018 report. The total number of pages in that firm's annual report (in the original PDF format) is 195.

${ }^{18}$ The reason we use annual reports while Caldara et al. (2019) construct quarterly measures is that the quarterly or the half-year reports of Chinese listed firms provide little information. In most cases, the information disclosed in the quarterly or the half-year reports will be reiterated in the annual reports.
} 
In the first step, we import annual reports with each line of transcript stored as an observation (see Figure E.4 for instance). In the second step, we search each line for the keywords related to uncertainty or future risk (regardless of whether they are related to trade policy), such as uncertainty and risk. Then, we count the frequency of these words in each line. Third, we isolate the uncertainty-related words that are also related to trade policy. We search each line for trade policy related keywords such as tariff, import duty, export tariff, protectionism, unilateralism, trade barriers, and anti-dumping..$^{19}$ Finally, our measure of trade policy uncertainty counts the number of cases in which we find uncertainty-related words and trade policy-related words in the same line. This count is then normalized by the length of the report. As a robustness check, we allow for more spacing between uncertainty and trade policy terms. Table 2 reports the keywords associated with uncertainty and trade policy we use.

Formally, the firm-level TPU measure for firm $i$ in year $t$ is provided by the following expression: ${ }^{20}$

$$
T P U_{i t}=\frac{1}{R_{i t}} \sum_{w=1}^{R_{i t}}\left\{\mathbb{1}\left[w \in \text { Keywords }^{\text {Uncertainty }}\right] \times \mathbb{1}[|w-t|<\text { One Line }]\right\}
$$

where $w=0,1, \ldots, R_{i t}$ are the words contained in the annual report of firm $i$ in year $t$; the length of report $R_{i t}$ is measured as the total number of Chinese characters; $t$ is the position of the nearest synonym of trade policy keywords (i.e., $t \in$ Keywords $^{\text {Trade policy }}$ ). In practice, we condition on a neighborhood of roughly 15 words before and after the appearance of uncertainty keywords. ${ }^{21}$

To corroborate that our constructed TPU measures capture firm-level variation in exposure to the U.S.-China trade war, we compare our TPU indices to those created by Davis et al. (2019) based on two mainland Chinese newspapers. ${ }^{22}$ We aggregate our firm-level series to create a national index and compare it with Davis et al. (2019). We plot both

\footnotetext{
${ }^{19}$ Figure E.5 provides an example to demonstrate the procedure, where the risk-related keywords marked by blue are not considered as trade policy uncertainty as there are no trade policy related keywords nearby. In contrast, the uncertainty keywords marked in red are classified as TPU because we also observe traderelated keywords ahead of these uncertainty keywords (i.e., protectionism and unilateralism).

${ }^{20}$ In addition to measuring TPU as the percentage of a report containing TPU keywords, we also experiment with the TPU measure based on the total number of keywords (i.e., $T P U_{i t}=\sum_{w=1}^{R_{i t}}\{\mathbb{1}[w \in$ Keywords $\left.^{\text {Uncertainty }}\right] \times \mathbb{1}[|w-t|<$ One Line $\left.]\right\}$ ). Results remain similar.

${ }^{21}$ That is, trade policy and uncertainty keywords are in the same line. For robustness, we also use a loose criteria - we require that the trade-related words are within one line (above or below) the line that contains uncertainty-related words. Table A.6 summarizes the firm-level exposure to TPU by year.

${ }^{22}$ The two newspapers are Renmin Daily and Guangming Daily. Their construction method follows Baker et al. (2016) who construct newspaper-based indices of economic policy uncertainty. The data is downloaded from https://www.policyuncertainty.com/trade_cimpr.html.
} 
Figure 7: TPU Based on Annual Report of Listed Firms and TPU in Davis et al. (2019)

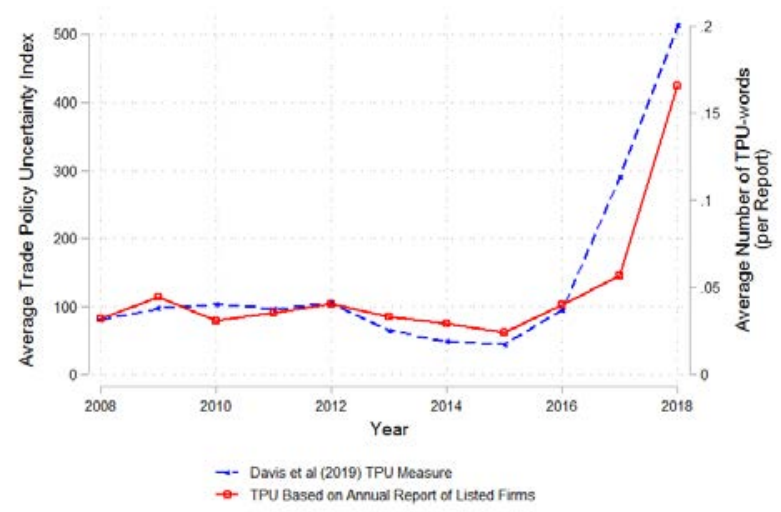

(a) Number of TPU Related Words Per Report

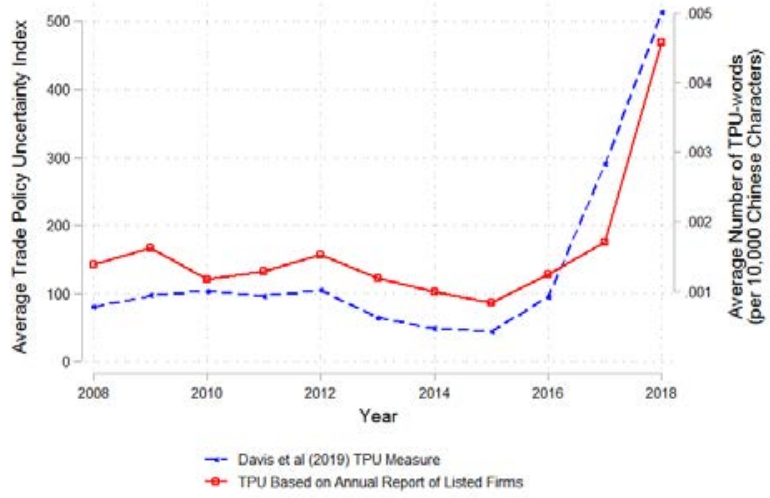

(b) Number of TPU Related Words (per 10,000 Chinese Characters)

Notes: A TPU keyword is identified if the trade-related words are in the same line with the uncertainty-related words. In panel (a), TPU is measured as the number of TPU related keywords per report; we also measure TPU using the number of TPU keywords per 10,000 Chinese characters as shown in panel (b).

series in Figure 7. Notably, the two series evolve closely, both when we create our index based on the total number of TPU instances (panel (a)) or the number of TPU instances normalized by the length of each report (panel (b)). Both series are fairly flat prior to 2016. In contrast, following Trump's election in November 2016, our TPU index based on annual reports increases by more than 300\% between 2016 and 2018. In Appendix Table A.7, we report the top ten most affected SIC 3-digit industries according to the mean TPU measure based on the number of keywords per report for China's listed firms. The mean industry-level measure is computed by averaging all firms in a particular industry. In panel (I), a TPU keyword is identified if the trade-related words are contained one line above or below the line which contains uncertainty-related words. In panel (II), we require that the trade-related words and the uncertainty words are both contained in the same line. Regardless of the choice of measure, we find that TPU most affected sectors related to textile and apparel manufacturing, fabricated metal products, and telephone communication \& transportation equipment. To sum up, our new TPU measures for Chinese firms during the trade war match the aggregate trends contained in Davis et al. (2019) while providing the first granular measures that document the evolution of Chinese firm-level TPU increases over this recent interval of changes in trade policy. ${ }^{23}$

\footnotetext{
${ }^{23}$ The TPU measure in Figure 7 is constructed following the rule that trade policy and uncertainty keywords are in the same line. In Figure E.6, the TPU measure is based on a loose criterion: the trade-related words are in one line above or below the place where there are uncertainty-related words, and a similar pattern is observed.
} 
Figure 8: TPU Measure and Pre-period Export Characteristics (2017 and 2018)

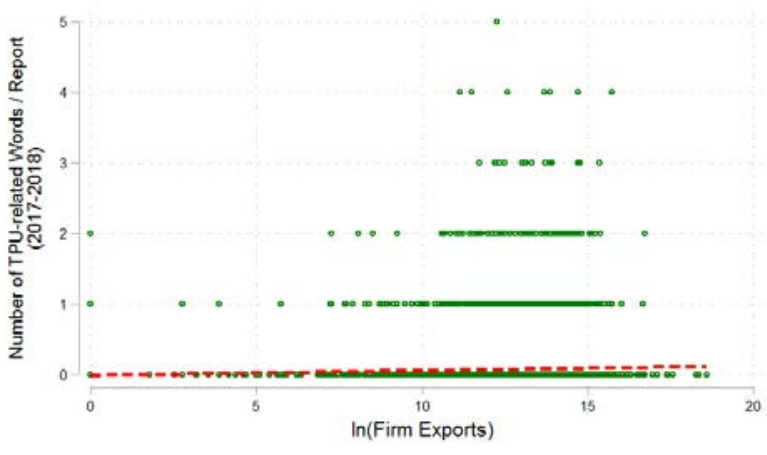

-. Fitted Line; $\beta=0.01 \mathrm{t}$-stat $=4.58$

(a) Firm Exports

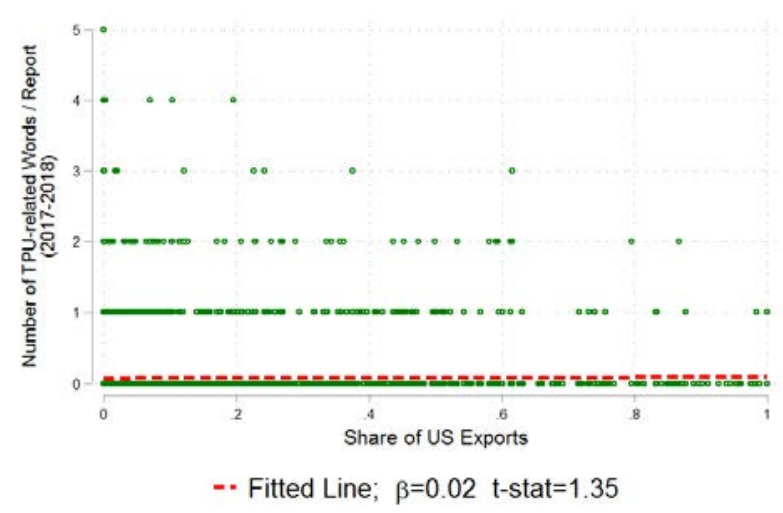

(c) Share of Exports to the United States

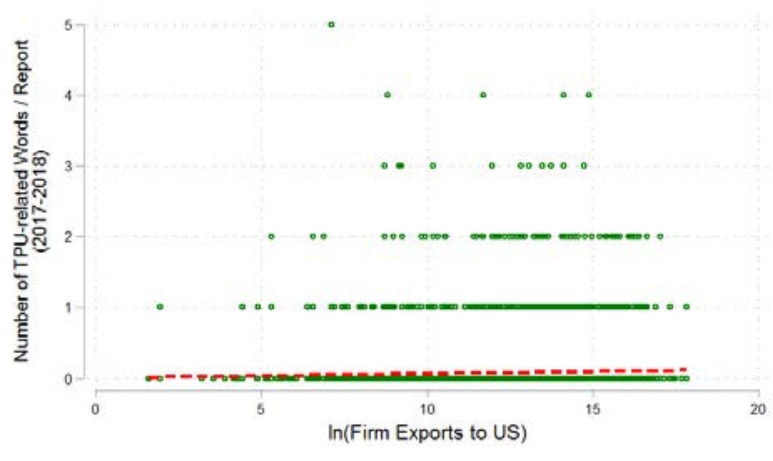

-. Fitted Line; $\beta=0.01 \mathrm{t}$-stat $=4.45$

(b) Firm Exports to the United States 
Figure 9: TPU Measure and Pre-period Import Characteristics (2017 and 2018)

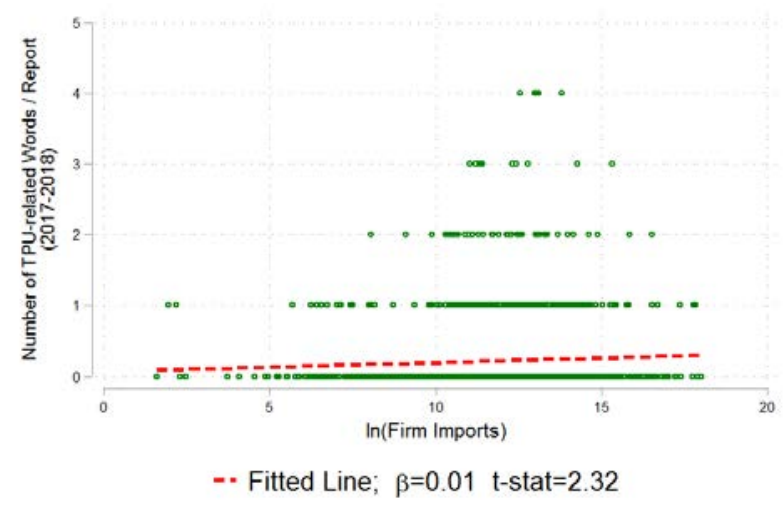

(a) Firm Imports

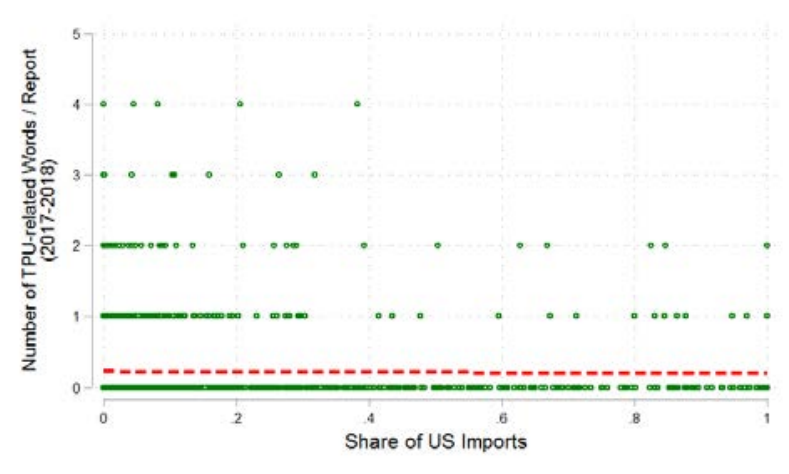

-- Fitted Line; $\beta=-0.03$ t-stat $=-0.52$

(c) Share of Imports from the United States

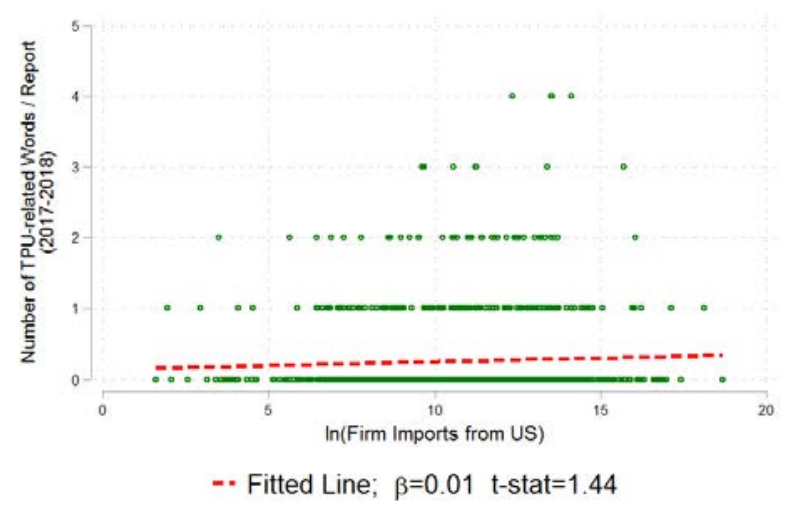

(b) Firm Imports from the United States

Figure 10: TPU Measure and Firm-level Tariff Exposure Measures (2017-2018)

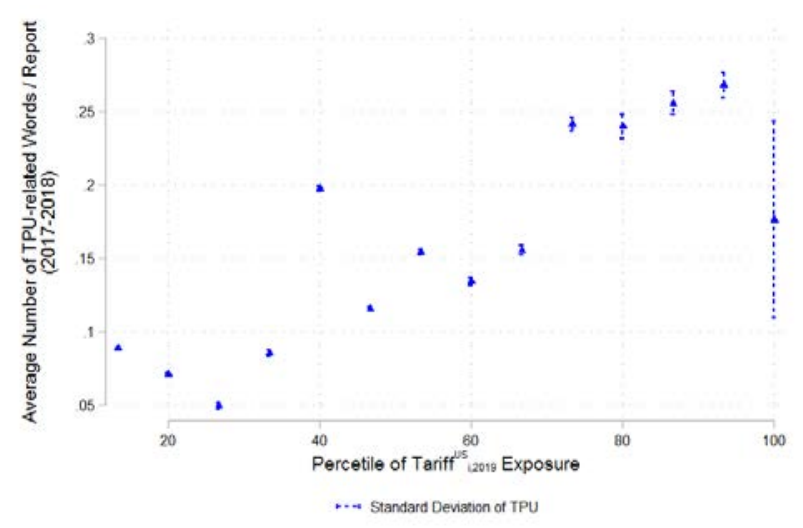

(a) U.S. Tariff on Chinese Goods (Tariff $i t$. .S.

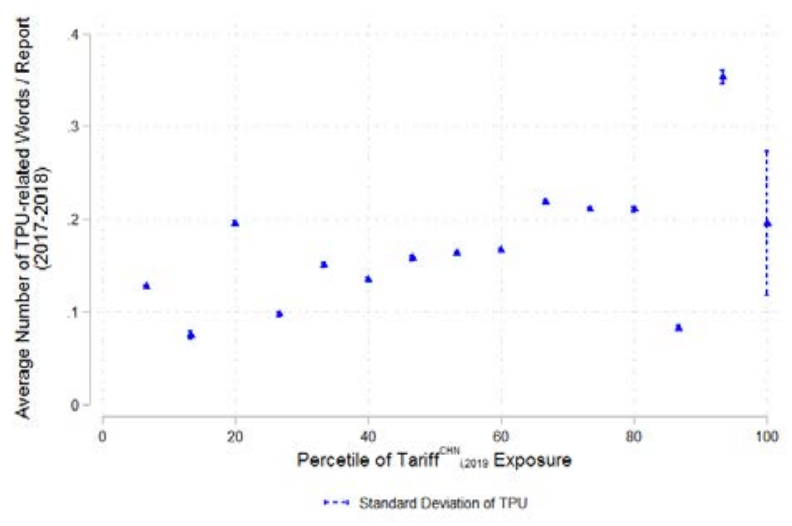

(b) Chinese Tariff on U.S. Goods (Tariff ${ }_{i t}^{\mathrm{CHN}}$ ) 
How does trade policy uncertainty relate to each firm's previous export and import activities? In Figure 8 we plot the average firm-level TPU measure against firm average exports in the pre-period (2013-2016) in panel (a). The slope coefficient is positive and significant, which indicates that firms exporting more in the pre-period experience greater TPU exposure during 2017 and 2018. Firms with larger exports to the U.S. experience larger TPU. In contrast, we do not observe that firms with a larger share of exports to the U.S. are likely to have greater TPU exposure. We repeat the same exercise for firm imports, as displayed in Figure 9. We find similar patterns on the import side: pre-period importing was associated with firm-level exposure to trade policy uncertainty during the trade war, while the share of imports from the U.S. is not correlated with TPU.

In Figure 10, we present the correlation between firm-level $T P U_{i t}$ and tariff exposure. In panel (a), we display firm average TPU by the percentile of exposure to the U.S. tariffs (Tariff $\left.\mathrm{U}_{i t}^{\mathrm{US}}\right)$, where each dot stands for the average TPU of firms in that group, and the dashed interval displays the standard deviation. It is clear that TPU is strongly correlated to the firm exposure to the U.S. tariffs on Chinese products, but still there are substantial differences in TPU among firms with high (Tariff $i t$.S. $)$. In contrast, the pattern becomes less clear in panel (b) where we relate TPU to the import tariff exposure Tariff ${ }_{i t}^{\mathrm{CHN}}$.

\section{Firm-level Impact of the 2018-2019 Trade War on TPU}

As we documented in the previous section, there is a positive correlation between our newly-constructed firm-level TPU measure and exposure to increased U.S. and Chinese tariffs. We now investigate the impact of trade war tariffs on firm-level TPU more formally by estimating the following regression in first-differences:

$$
\Delta \mathrm{TPU}_{i}=\alpha+\beta \Delta \log \left(1+\operatorname{Tariff}_{i}^{\mathrm{USS}}\right)+\gamma \Delta \log \left(1+\operatorname{Tariff}_{i}^{\mathrm{CHN}}\right)+\delta X_{i}+\psi_{\mathrm{REG}}+\psi_{\mathrm{IND}}+\varepsilon_{i}
$$

where $\Delta$ denotes changes between 2017Q4 and 2018Q4. ${ }^{24}$ The dependent variable, $\Delta \mathrm{TPU}_{i}$, measures the change in firm $i$ 's trade policy uncertainty measure between 2017Q4 and 2018Q4. ${ }^{25}$ The independent variable $\Delta \log \left(1+\right.$ Tariff $\left._{i}^{\text {U.S. }}\right)$ denotes the change in Tariff ${ }_{i}^{\text {U.S. }}$

\footnotetext{
${ }^{24}$ Since annual reports are issued on a yearly basis, there is a single firm-level TPU measure per year. The most recent measure available for our project corresponds to 2018. The trade war tariff increases started in 2018Q3. Hence, we use two data points, i.e., 2017Q4 and 2018Q4, to study the impact of firm-level tariff shocks on firm-level TPU. Note also that when $T=2$, the first-difference estimator and fixed effects estimator are equivalent.

${ }^{25}$ More specifically, we follow equation (3) to define TPU as the percentage of a report containing TPU keywords. Here, a TPU keywords is identified if the trade-related words are in one line above or below the place where there are uncertainty-related words; the denominator is the total number of Chinese characters. Because the mean and standard deviation of TPU are very small numbers, without loss of generality, we multiply this measure by 100,000 in practice. The mean and standard deviation of adjusted TPU are 0.117
} 
between 2017Q4 and 2018Q4, where Tariff ${ }_{i}^{\text {U.S. }}$ is firm $i$ 's exposure to U.S. tariffs on Chinese imports. Likewise, $\Delta \log \left(1+\operatorname{Tariff}_{i}^{\mathrm{CHN}}\right)$ denotes the change in Tariff ${ }_{i}^{\mathrm{CHN}}$ between 2017Q4 and 2018Q4, where Tariff ${ }_{i}^{\mathrm{CHN}}$ is a measure of firm $i$ 's exposure to Chinese tariffs on its imports from the U.S. We also control for firm characteristics in $X_{i}$, which includes revenue, capital and profits in 2017Q4. We control for region- $\left(\psi_{\text {REG }}\right)$ and industry- $\left(\psi_{\text {IND }}\right)$ specific trends with fixed effects. ${ }^{26}$

Table 3: Trade Policy Uncertainty and Tariffs: 2017Q4-2018Q4

\begin{tabular}{|c|c|c|c|c|c|}
\hline & \multicolumn{5}{|c|}{$\begin{array}{c}\text { Dependent Variable: } \\
\Delta \text { Trade Policy Uncertainty }\end{array}$} \\
\hline & $(1)$ & $(2)$ & (3) & $(4)$ & $(5)$ \\
\hline$\Delta \log \left(1+\right.$ Tariff $\left.^{\text {U.S. }}\right)$ & $\begin{array}{c}0.314^{* * *} \\
(0.121)\end{array}$ & & $\begin{array}{l}0.245^{*} \\
(0.125)\end{array}$ & $\begin{array}{c}0.131 \\
(0.128)\end{array}$ & $\begin{array}{c}0.126 \\
(0.133)\end{array}$ \\
\hline$\Delta \log \left(1+\right.$ Tariff $\left.^{\mathrm{CHN}}\right)$ & & $\begin{array}{l}0.701^{* *} \\
(0.296)\end{array}$ & $\begin{array}{c}0.569^{*} \\
(0.307)\end{array}$ & $\begin{array}{l}0.722^{* *} \\
(0.303)\end{array}$ & $\begin{array}{l}0.668^{* *} \\
(0.310)\end{array}$ \\
\hline Firm Characteristics & No & No & No & No & Yes \\
\hline Region FE & No & No & No & Yes & Yes \\
\hline Industry FE & No & No & No & Yes & Yes \\
\hline Observations & 2,180 & 2,180 & 2,180 & 2,168 & 2,135 \\
\hline R-squared & 0.003 & 0.003 & 0.005 & 0.078 & 0.081 \\
\hline
\end{tabular}

Notes: The dependent variable is the change in firm-level trade policy uncertainty between 2017Q4 and 2018Q4. Tariff ${ }^{\mathrm{U} . S}$. denotes the firm-level measure of exposure to U.S. tariffs on imports from China, computed as a weighted average across each firm's set of products exported to the U.S. Tariff ${ }^{\mathrm{CHN}}$ denotes the firm-level measure of exposure to Chinese tariffs on imports from the U.S., computed as a weighted average across each firm's set of products imported from the U.S. $\Delta \log \left(1+\right.$ Tariff $\left.^{\text {U.S. }}\right)$ and $\Delta \log \left(1+\right.$ Tariff $\left.^{\mathrm{CHN}}\right)$ are percent changes in Tariff ${ }^{\text {U.S. }}$ and Tariff ${ }^{\mathrm{CHN}}$ between 2017Q4 and 2018Q4. Firm characteristics include profit, revenue and capital and are measured in 2017Q4. Industries are defined according to the 3-digit Standard Industrial Classification (SIC). Robust standard errors are in parentheses. ${ }^{* * *} \mathrm{p}<0.01,{ }^{* *} \mathrm{p}<0.05,{ }^{*}$ $\mathrm{p}<0.1$.

Table 3 displays our estimation results. In column (1), we report the impact of U.S. tariffs on firm-level TPU in the absence of control variables. The coefficient is positive and statistically significant, implying that U.S. tariffs, which act as a barrier on Chinese exports to the U.S., increase TPU. The coefficient of 0.314 indicates that a ten percentage

and 0.425 , respectively, in the year 2017 .

${ }^{26}$ The administrative units are currently based on a three-level system in China. The country is first divided into provincial units, including provinces (e.g., Jiangsu Province), autonomous regions (e.g., Tibet), and municipalities directly under the central government (e.g., Beijing, Shanghai, Chongqing, and Tianjin). Prefecture-level divisions are the second level of the administrative structure, and most provincial units except municipalities are divided into only prefecture-level cities without any other units. In this paper, each region refers to the unit in the first level of the administrative structure - autonomous regions, province municipal city (i.e., municipality) and province. For details, see http://xzqh.mca.gov.cn/statistics/ 2018. html. Industry is defined at the SIC-3-digit level and the number of industries in the sample is 112. 
point increase in the U.S. tariff exposure measure is associated with a 0.031 point $(0.074$ standard deviations) increase in TPU. In column (2), we report the impact of Chinese tariffs - which limit Chinese firms' imports from the U.S. - on TPU, again in the absence control variables. Here too, we find a positive and statistically significant relationship. The coefficient of 0.701 indicates that a ten percentage point increase in the Chinese tariff exposure measure is associated with a 0.070 point ( 0.165 standard deviations) increase in TPU. In column (3) when we include U.S. and Chinese tariffs together, the coefficients remain similar in magnitude and remain statistically significant.

We next explore whether our results were affected by selection effects, since the set of products targeted by tariffs may have been shaped by governments' strategic decisions. For example, the Trump administration imposed higher tariffs on Chinese goods in IT or high-tech-related industries. Hence, unobserved industry characteristics might simultaneously increase trade policy uncertainty and tariffs. To alleviate the concern about the endogeneity of tariffs (i.e., targeting certain industries), we add region and SIC-3digit level industry fixed effects, which can absorb region- and industry-specific trends in trade policy uncertainty, in column (4) of Table 3. The coefficient on U.S. tariff exposure remains positive, but is no longer statistically significant. The coefficient for Chinese tariff exposure is still positive and statistically significant. The column (4) coefficients can be interpreted as changes in firm-level TPU due to differences in tariff exposure across firms, controlling for region and industry fixed effects. Finally, in column (5), we control for observable lagged firm-level characteristics such as revenue, capital and profit. This specification addresses the potential concern that larger and/or more capital-intensive firms may have experienced increases in both firm-level tariffs and trade policy uncertainty. However, the results change little when these controls are added to the estimating equation. Quantitatively, a ten percentage point increase in the Chinese tariff exposure measure is associated with a 0.067 point ( 0.157 standard deviations) increase in TPU.

\subsection{Pre-Existing Trends}

Another potential concern is that tariffs may have targeted particular firms (e.g., large Chinese exporters within an industry) and that those firms also had a pre-existing trend in TPU (i.e., those firms were already exhibiting a steeper increase in TPU than other firms within their industry). In order to alleviate this concern, we check for pre-existing trends in firm-level trade policy uncertainty. We regress the change in firm $i$ 's trade policy uncertainty between 2016Q4 and 2017Q4 against the change in firm $i$ 's tariff exposure 
measures between 2017Q4 and 2018Q4 as follows:

$$
\begin{aligned}
\Delta_{16 Q 4-17 Q 4} \mathrm{TPU}_{i} & =\alpha+\beta \Delta_{17 Q 4-18 Q 4} \log \left(1+\operatorname{Tariff}_{i}^{\text {U.S. }}\right)+\gamma \Delta_{17 Q 4-18 Q 4} \log \left(1+\operatorname{Tariff}_{i}^{\mathrm{CHN}}\right) \\
& +\delta X_{i}+\psi_{\mathrm{REG}}+\psi_{\mathrm{IND}}+\varepsilon_{i}
\end{aligned}
$$

where $\Delta_{16 Q 4-17 Q 4}$ denotes the change between 2016Q4 and 2017Q4 and $\Delta_{17 Q 4-18 Q 4}$ denotes the change between 2017Q4 and 2018Q4.

Table 4: Tests for Pre-Existing Trends

\begin{tabular}{lccccc}
\hline \hline & \multicolumn{5}{c}{ Dependent Variable: } \\
& $\Delta_{16 Q 4}-17 Q 4$ & Trade Policy Uncertainty \\
& $(1)$ & $(2)$ & $(3)$ & $(4)$ & $(5)$ \\
\hline & & & & & \\
$\Delta_{17 Q 4-18 Q 4} \log \left(1+\right.$ Tariff $\left.^{\mathrm{U} . S .}\right)$ & 0.011 & & 0.009 & -0.024 & -0.004 \\
& $(0.082)$ & & $(0.085)$ & $(0.093)$ & $(0.095)$ \\
$\Delta_{17 Q 4-18 Q 4} \log (1+$ Tariff & & & \\
& & 0.022 & 0.017 & -0.031 & -0.000 \\
& & $(0.214)$ & $(0.222)$ & $(0.225)$ & $(0.229)$ \\
Firm Characteristics & No & No & No & No & Yes \\
Region FE & No & No & No & Yes & Yes \\
Industry FE & No & No & No & Yes & Yes \\
Observations & 2,028 & 2,028 & 2,028 & 2,017 & 1,984 \\
R-squared & 0.000 & 0.000 & 0.000 & 0.081 & 0.083 \\
\hline \hline
\end{tabular}

Notes: The dependent variable is the change in firm-level trade policy uncertainty between 2016Q4 and 2017Q4. Tariff U.S. denotes a firm-level measure of exposure to U.S. tariffs on imports from China, computed as a weighted average across each firm's set of products exported to the U.S. Tariff ${ }^{\mathrm{CHN}}$ denotes a firm-level measure of tariff to Chinese tariffs on imports from the U.S., computed as a weighted average across each firm's set of products imported from the U.S. $\Delta \log \left(1+\right.$ Tariff $\left.^{\text {U.S. }}\right)$ and $\Delta \log \left(1+\right.$ Tariff $\left.^{\mathrm{CHN}}\right)$ are percent changes in Tariff ${ }^{\mathrm{U} . S .}$ and Tariff ${ }^{\mathrm{CHN}}$ between 2017Q4 and 2018Q4. Firm characteristics include profit, revenue and capital and are measured in 2017Q4. Industries are defined according to the 3-digit Standard Industrial Classification (SIC). Robust standard errors are in parentheses. ${ }^{* *} \mathrm{p}<0.01,{ }^{* *}$ $\mathrm{p}<0.05,{ }^{*} \mathrm{p}<0.1$.

Table 4 reports these pre-trend tests for trade policy uncertainty. Across all specifications, we do not find any statistically significant relationship between pre-period changes in trade policy uncertainty and tariff changes.

\subsection{Heterogeneity in TPU Response}

Firm Size and Capital Intensity Next, we explore whether the trade war tariffs differentially impacted firm trade policy uncertainty depending on firm size. To this end, we 
augment our baseline equation with two interaction terms as follows:

$$
\begin{aligned}
\Delta \mathrm{TPU}_{i} & =\alpha+\beta_{1} \Delta \log \left(1+\text { Tariff }_{i}^{\text {U.S. }}\right)+\beta_{2} \Delta \log \left(1+\text { Tariff }_{i}^{\text {U.S. }}\right) \times \log \left(\text { Revenue }_{i}\right) \\
& +\gamma_{1} \Delta \log \left(1+\operatorname{Tariff}_{i}^{\mathrm{CHN}}\right)+\gamma_{2} \Delta \log \left(1+\operatorname{Tariff}_{i}^{\mathrm{CHN}}\right) \times \log \left(\text { Revenue }_{i}\right) \\
& +\delta X_{i}+\psi_{\mathrm{REG}}+\psi_{\mathrm{IND}}+\varepsilon_{i}
\end{aligned}
$$

where the $\beta_{2}$ coefficient captures the differential impact of firm-level exposure to U.S. tariffs on trade policy uncertainty for firms of different sizes, while $\gamma_{2}$ captures the differential impact of firm-level exposure to Chinese tariffs.

In column (1) of Table 5, we start by estimating the equation with firm-level U.S. tariff exposure and its interaction term with log revenue, which is our measure of firm size. The coefficient $\beta_{2}$ is negative and statistically significant. In column (2), we relate trade policy uncertainty to firm-level Chinese tariff exposure and its interaction term with log revenue. We find that $\gamma_{2}$ is negative and statistically significant. In column (3), we then estimate the full equation above and find that the coefficient $\beta_{2}$ is -0.231 (and statistically significant at the 5 percent level) and that the coefficient $\gamma_{2}$ is -0.233 and statistically insignificant. Hence, we conclude that only the impact of U.S. tariff exposure on trade policy uncertainty differs across firms of different sizes. As the estimated effect of the U.S. tariffs on TPU is $1.563-0.231 \times \log \left(\right.$ Revenue $\left._{i}\right)$, the effect on TPU would be zero when $\log \left(\right.$ Revenue $\left._{i}\right)=6.77$ which is positioned at the 67 th percentile of $\log \left(\right.$ Revenue $\left._{i}\right) .{ }^{27}$

We next turn our attention to response differences across firms as related to differences in firms' size as measured by capital stocks. We thus replace the log revenue interaction terms with new interaction terms that use log capital. Then, we repeat the analysis from columns (4) to (6) in Table 5. In column (6), when both U.S. and Chinese tariffs are considered $\beta_{2}$ and $\gamma_{2}$ are negative and statistically significant. This implies that the impact of U.S. tariffs and/or Chinese tariff exposure on trade policy uncertainty is mitigated as firms' capital stock increases. As the estimated effect of the U.S. tariffs on TPU is $1.331-0.188 \times \log \left(\right.$ Capital $\left._{i}\right)$, the effect on TPU would be zero when $\log \left(\right.$ Capital $\left._{i}\right)=7.08$ which is positioned at the 69 th percentile of the $\log \left(\right.$ Capital $\left._{i}\right){ }^{28}$

In both cases (i.e., revenue and capital), the results suggest that the increased tariffs elevated TPU for the smallest two thirds of firms. One explanation could be that these firms might have benefited most from using U.S. sourcing to improve the quality of their products, which previously was facilitated by trade liberalization. Consequently, if Chinese

\footnotetext{
${ }^{27}$ The impact of U.S. tariffs on trade policy uncertainty is 0.231 points ( 0.544 standard deviations) lower as a firm's revenue doubles.

${ }^{28}$ Quantitatively, as a firm's capital stocks double, the impact U.S. tariffs on trade policy uncertainty is 0.188 points ( 0.443 standard deviations) lower, while the impact of Chinese tariffs on trade policy uncertainty is 0.367 points ( 0.864 standard deviations) lower.
} 
Table 5: Trade Policy Uncertainty, Tariffs, and Size: 2017Q4-2018Q4

\begin{tabular}{|c|c|c|c|c|c|c|}
\hline & \multicolumn{6}{|c|}{ Dependent Variable: $\Delta$ Trade Policy Uncertainty } \\
\hline & \multicolumn{3}{|c|}{ Interaction with Revenue } & \multicolumn{3}{|c|}{ Interaction with Capital } \\
\hline & $(1)$ & $(2)$ & (3) & $(4)$ & $(5)$ & $(6)$ \\
\hline$\Delta \log \left(1+\right.$ Tariff $\left.^{\text {U.S. }}\right)$ & $\begin{array}{c}1.800^{* * *} \\
(0.589)\end{array}$ & & $\begin{array}{l}1.563^{* *} \\
(0.609)\end{array}$ & $\begin{array}{c}1.687^{* * *} \\
(0.592)\end{array}$ & & $\begin{array}{l}1.331^{* *} \\
(0.609)\end{array}$ \\
\hline$\Delta \log \left(1+\right.$ Tariff $\left.{ }^{\mathrm{CHN}}\right)$ & & $\begin{array}{l}3.314^{* *} \\
(1.375)\end{array}$ & $\begin{array}{c}2.238 \\
(1.407)\end{array}$ & & $\begin{array}{c}4.060^{* * *} \\
(1.321)\end{array}$ & $\begin{array}{l}3.187^{* *} \\
(1.343)\end{array}$ \\
\hline$\Delta \log \left(1+\right.$ Tariff $\left.^{\text {U.S. }}\right) \times \log ($ Revenue $)$ & $\begin{array}{c}-0.255^{* * *} \\
(0.095)\end{array}$ & & $\begin{array}{c}-0.231^{* *} \\
(0.098)\end{array}$ & & & \\
\hline$\Delta \log \left(1+\right.$ Tariff $\left.^{\mathrm{CHN}}\right) \times \log ($ Revenue $)$ & & $\begin{array}{l}-0.392^{*} \\
(0.213)\end{array}$ & $\begin{array}{l}-0.233 \\
(0.219)\end{array}$ & & & \\
\hline$\Delta \log \left(1+\right.$ Tariff $\left.^{\mathrm{U} . S} \cdot\right) \times \log ($ Capital $)$ & & & & $\begin{array}{c}-0.230^{* *} \\
(0.094)\end{array}$ & & $\begin{array}{c}-0.188^{*} \\
(0.096)\end{array}$ \\
\hline$\Delta \log \left(1+\right.$ Tariff $\left.^{\mathrm{CHN}}\right) \times \log ($ Capital $)$ & & & & & $\begin{array}{c}-0.490^{* * *} \\
(0.189)\end{array}$ & $\begin{array}{l}-0.367^{*} \\
(0.193)\end{array}$ \\
\hline Firm Characteristics & Yes & Yes & Yes & Yes & Yes & Yes \\
\hline Region FE & Yes & Yes & Yes & Yes & Yes & Yes \\
\hline Industry FE & Yes & Yes & Yes & Yes & Yes & Yes \\
\hline Observations & 2,135 & 2,135 & 2,135 & 2,135 & 2,135 & 2,135 \\
\hline R-squared & 0.082 & 0.082 & 0.085 & 0.081 & 0.084 & 0.086 \\
\hline
\end{tabular}

Notes: The dependent variable is the change in firm-level trade policy uncertainty between 2017Q4 and 2018Q4. Tariff ${ }^{\text {U.S. }}$ denotes the firm-level measure of exposure to U.S. tariffs on imports from China, computed as a weighted average across each firm's set of products exported to the U.S. Tariff ${ }^{\mathrm{CHN}}$ denotes the firm-level measure of tariff to Chinese tariffs on imports from the U.S., computed as a weighted average across each firm's set of products imported from the U.S. $\Delta \log \left(1+\right.$ Tariff $\left.^{\text {U.S. }}\right)$ and $\Delta \log \left(1+\right.$ Tariff $\left.^{\text {CHN }}\right)$ are percent changes in Tariff ${ }^{\text {U.S. }}$ and Tariff ${ }^{\mathrm{CHN}}$ between 2017Q4 and 2018Q4. Firm characteristics include profit, revenue and capital and are measured in 2017Q4. Industries are defined according to the 3-digit Standard Industrial Classification (SIC). Robust standard errors are in parentheses. ${ }^{* *} \mathrm{p}<0.01,{ }^{* *} \mathrm{p}<0.05,{ }^{*} \mathrm{p}<0.1$.

firms were sourcing optimally before the trade war, the reversal of opportunities due to the trade war implies that the damage would be greatest for these firms which are likely to be characterized by low capital intensity, small revenue and low productivity (Fan, Li and Yeaple, 2018). ${ }^{29}$

Trade Diversification In addition to the quality channel, the effect of tariffs on TPU could also depend on firms' product and market diversification patterns. Firm-level diversification will matter if the detrimental economic impacts of trade was tariff shocks could be mitigated by strategically switching markets or by re-allocating sales across products. This implies that the adverse effects of firm-level TPU rises should have been smaller for more internationally diversified firms as measured by the number of partner

\footnotetext{
${ }^{29} \mathrm{Fan}, \mathrm{Li}$ and Yeaple (2018) find that, around the time of China's WTO accession, lower productivity firms benefited more from the accession due to the quality upgrading that was facilitated by trade liberalization.
} 
countries and the number of products.

To operationalize the idea of diversification, we exploit the detailed firm-productcountry-level at which firm trade transactions are reported in the Chinese customs data. To start, this allows us to calculate the total number of exported products and destination markets (and the total number of imported products and source countries) between 2013 and 2016 at the firm-level. Then, we incorporate them in our baseline equation as follows:

$$
\begin{aligned}
\Delta \mathrm{TPU}_{i} & =\alpha+\beta_{1} \Delta \log \left(1+\text { Tariff }_{i}^{\mathrm{U} . S .}\right)+\beta_{2} \Delta \log \left(1+\operatorname{Tariff}_{i}^{\mathrm{U} . \mathrm{S} .}\right) \times N_{i}^{\text {exp }, \text { prod }} \\
& +\gamma_{1} \Delta \log \left(1+\operatorname{Tariff}_{i}^{\mathrm{CHN}}\right)+\gamma_{2} \Delta \log \left(1+\operatorname{Tariff}_{i}^{\mathrm{CHN}}\right) \times N_{i}^{\text {imp,prod }} \\
& +N_{i}^{\text {exp,prod }}+N_{i}^{\text {imp,prod }}+\delta X_{i}+\psi_{\mathrm{REG}}+\psi_{\mathrm{IND}}+\varepsilon_{i}
\end{aligned}
$$

where $N_{i}^{\text {exp,prod }}$ and $N_{i}^{\text {imp,prod }}$ are the total number of exported and imported products for firm $i$ from 2013 to 2016. Coefficient $\beta_{2}$ captures the differential impact of firm-level exposure to U.S. tariffs on trade policy uncertainty across firms as mediated by firm-level differences in the numbers of exported products, and $\gamma_{2}$ captures the differential impact of firm-level exposure to Chinese tariffs across firms as it varies across firms with different numbers of imported products.

Columns 1 through 3 in Table 6 display the results. Across all specifications, the interaction terms are statistically insignificant, suggesting that more diverse product import or export scope did not reduce Chinese firms' perceived trade policy uncertainty. Next, we replace the total number of products with the total number of countries a firm exports to or imports from ( $N_{i}^{\text {exp,ctry }}$ and $N_{i}^{i m p, c t r y}$, respectively), and report results in columns 4 through 6. According to column (6), faced with an increase in U.S. tariffs of the same magnitude, firms exporting to more countries registered smaller increases in TPU. One additional country in a firm's export basket reduces the impact of U.S. tariffs on firm-level TPU by 0.012 points (0.028 standard deviations). However, we do not find any evidence suggesting that importing from more countries mitigates the impact of Chinese tariffs on TPU. These results are also consistent with the previous findings that the TPU increase is less pronounced for larger firms (by revenue or capital) which are also more diversified in trade partners and traded products. ${ }^{30}$

To sum up, multi-country exporters perceive less uncertainty after an increase in tariffs, presumably due to their ability to re-route trade (see Kramarz et al., 2020; Caselli et al., 2020). In addition, the result may suggest an element of sunk costs in Chinese firms' exporting. If there are sunk costs of searching for trade partners, or fixed investments that are placed as new export destinations are created, the existence of established trade

\footnotetext{
${ }^{30}$ However, we are agnostic on the effect of TPU on product mix changes, which may be an avenue of future research on the mechanisms behind TPU effects.
} 
Table 6: Trade Policy Uncertainty, Tariffs, and Diversification: 2017Q4-2018Q4

\begin{tabular}{|c|c|c|c|c|c|c|}
\hline & \multicolumn{6}{|c|}{ Dependent Variable: $\Delta$ Trade Policy Uncertainty } \\
\hline & \multicolumn{3}{|c|}{ Number of Products } & \multicolumn{3}{|c|}{ Number of Partner Countries } \\
\hline & $(1)$ & $(2)$ & $(3)$ & $(4)$ & $(5)$ & $(6)$ \\
\hline$\Delta \log \left(1+\right.$ Tariff $\left.^{\text {U.S. }}\right)$ & $\begin{array}{l}0.271^{*} \\
(0.151)\end{array}$ & & $\begin{array}{c}0.173 \\
(0.152)\end{array}$ & $\begin{array}{l}0.572^{* * *} \\
(0.192)\end{array}$ & & $\begin{array}{l}0.392^{* *} \\
(0.192)\end{array}$ \\
\hline$\Delta \log \left(1+\right.$ Tariff $\left.^{\mathrm{U} . \mathrm{S}}\right) \times N_{i}^{\text {exp,prod }}$ & $\begin{array}{l}-0.003 \\
(0.002)\end{array}$ & & $\begin{array}{l}-0.003 \\
(0.002)\end{array}$ & & & \\
\hline$\Delta \log \left(1+\right.$ Tariff $\left.^{\text {U.S. }}\right) \times N_{i}^{\text {exp }, c t r y}$ & & & & $\begin{array}{c}-0.016^{* * *} \\
(0.005)\end{array}$ & & $\begin{array}{l}-0.012^{* *} \\
(0.005)\end{array}$ \\
\hline$\Delta \log \left(1+\right.$ Tariff $\left.^{\mathrm{CHN}}\right)$ & & $\begin{array}{l}0.764^{* *} \\
(0.373)\end{array}$ & $\begin{array}{l}0.732^{* *} \\
(0.366)\end{array}$ & & $\begin{array}{l}0.577 \\
(0.459)\end{array}$ & $\begin{array}{c}0.570 \\
(0.471)\end{array}$ \\
\hline$\Delta \log \left(1+\right.$ Tariff $\left.^{\mathrm{CHN}}\right) \times N_{i}^{\text {imp,prod }}$ & & $\begin{array}{l}-0.005 \\
(0.010)\end{array}$ & $\begin{array}{l}-0.006 \\
(0.009)\end{array}$ & & & \\
\hline$\Delta \log \left(1+\right.$ Tariff $\left.{ }^{\mathrm{CHN}}\right) \times N_{i}^{i m p, c t r y}$ & & & & & $\begin{array}{c}-0.019 \\
(0.035)\end{array}$ & $\begin{array}{l}-0.019 \\
(0.035)\end{array}$ \\
\hline$N_{i}^{\text {exp,prod }}$ & $\begin{array}{c}0.000 \\
(0.000)\end{array}$ & & $\begin{array}{c}0.000 \\
(0.000)\end{array}$ & & & \\
\hline$N_{i}^{i m p, p r o d}$ & & $\begin{array}{c}0.001 \\
(0.001)\end{array}$ & $\begin{array}{c}0.001 \\
(0.001)\end{array}$ & & & \\
\hline$N_{i}^{e x p, c t r y}$ & & & & $\begin{array}{l}0.002^{*} \\
(0.001)\end{array}$ & & $\begin{array}{c}0.000 \\
(0.001)\end{array}$ \\
\hline$N_{i}^{i m p, c t r y}$ & & & & & $\begin{array}{l}0.005^{* *} \\
(0.002)\end{array}$ & $\begin{array}{l}0.006^{* *} \\
(0.003)\end{array}$ \\
\hline Firm Characteristics & Yes & Yes & Yes & Yes & Yes & Yes \\
\hline Region FE & Yes & Yes & Yes & Yes & Yes & Yes \\
\hline Industry FE & Yes & Yes & Yes & Yes & Yes & Yes \\
\hline Observations & 2,135 & 2,135 & 2,135 & 2,135 & 2,135 & 2,135 \\
\hline R-squared & 0.080 & 0.081 & 0.083 & 0.082 & 0.083 & 0.087 \\
\hline
\end{tabular}

Notes: The dependent variable is the change in firm-level trade policy uncertainty between 2017Q4 and 2018Q4. Tariff U.S. denotes the firm-level measure of exposure to U.S. tariffs on imports from China, computed as a weighted average across each firm's set of products exported to the U.S. Tariff ${ }^{\mathrm{CHN}}$ denotes the firm-level measure of tariff to Chinese tariffs on imports from the U.S., computed as a weighted average across each firm's set of products imported from the U.S. $\Delta \log \left(1+\right.$ Tariff ${ }^{\text {U.S. }}$ ) and $\Delta \log \left(1+\right.$ Tariff $\left.^{\mathrm{CHN}}\right)$ are percent changes in Tariff ${ }^{\mathrm{U} . S}$. and Tariff ${ }^{\mathrm{CHN}}$ between $2017 \mathrm{Q} 4$ and 2018Q4. Firm characteristics include profit, revenue and capital and are measured in 2017Q4. Industries are defined according to the 3-digit Standard Industrial Classification (SIC). Robust standard errors are in parentheses. ${ }^{* * *} \mathrm{p}<0.01,{ }^{* *} \mathrm{p}<0.05,{ }^{*} \mathrm{p}<0.1$.

partners helps to explain the diversification effects.

Dependence on U.S. Sales Although most firms are active in a number of markets for sales and/or sourcing, the U.S. is the dominant connection for many. If firms have excessive dependence on U.S. sales, given the fixed costs of locating and entering new markets, the ability to hedge in export markets might be hampered. To test this hypothesis, we con- 
struct measures of U.S. reliance based on firm trade prior to the trade war. Specifically, $D_{i}^{\text {exp, U.S.-dominant }}\left(D_{i}^{\text {imp, U.S.-dominant }}\right)$ is a dummy variable that equals one if the firm's U.S. exports (imports) as the share of its total exports (imports) is greater than some critical values. The two variables are incorporated into our baseline regression in the form of interactions with the tariff exposure variables.

Table 7: Trade Policy Uncertainty, Tariffs, and U.S. Dependence: 2017Q4-2018Q4

\begin{tabular}{|c|c|c|c|c|c|c|c|}
\hline & \multicolumn{7}{|c|}{ Dependent Variable: $\Delta$ Trade Policy Uncertainty } \\
\hline & $\frac{\text { Cuto }}{(1)}$ & $\frac{\text { of } D:}{(2)}$ & $\frac{5 \%}{(3)}$ & $\frac{5 \%}{(4)}$ & $\frac{10 \%}{(5)}$ & $\frac{15 \%}{(6)}$ & $\frac{20 \%}{(7)}$ \\
\hline$\Delta \log \left(1+\right.$ Tariff $\left.^{\text {U.S. }}\right)$ & $\begin{array}{c}0.126 \\
(0.133)\end{array}$ & $\begin{array}{l}0.427^{* *} \\
(0.194)\end{array}$ & $\begin{array}{c}-0.278 \\
(0.212)\end{array}$ & $\begin{array}{c}0.023 \\
(0.244)\end{array}$ & $\begin{array}{c}0.100 \\
(0.237)\end{array}$ & $\begin{array}{c}0.099 \\
(0.231)\end{array}$ & $\begin{array}{c}0.169 \\
(0.232)\end{array}$ \\
\hline$\Delta \log \left(1+\right.$ Tariff $\left.^{\mathrm{CHN}}\right)$ & $\begin{array}{l}0.668^{* *} \\
(0.310)\end{array}$ & $\begin{array}{c}0.477 \\
(0.444)\end{array}$ & $\begin{array}{c}0.284 \\
(1.874)\end{array}$ & $\begin{array}{c}0.141 \\
(1.865)\end{array}$ & $\begin{array}{c}0.054 \\
(1.137)\end{array}$ & $\begin{array}{c}0.864 \\
(1.118)\end{array}$ & $\begin{array}{c}0.787 \\
(1.107)\end{array}$ \\
\hline$\Delta \log \left(1+\right.$ Tariff $\left.^{\text {U.S. }}\right) \times N_{i}^{e x p, c t r y}$ & & $\begin{array}{c}-0.009^{* *} \\
(0.004)\end{array}$ & & $\begin{array}{c}-0.009^{* *} \\
(0.004)\end{array}$ & $\begin{array}{c}-0.009^{* *} \\
(0.004)\end{array}$ & $\begin{array}{c}-0.009^{* *} \\
(0.004)\end{array}$ & $\begin{array}{c}-0.009^{* *} \\
(0.004)\end{array}$ \\
\hline$\Delta \log \left(1+\right.$ Tariff $\left.^{\mathrm{CHN}}\right) \times N_{i}^{i m p, c t r y}$ & & $\begin{array}{c}0.016 \\
(0.028)\end{array}$ & & $\begin{array}{c}0.014 \\
(0.028)\end{array}$ & $\begin{array}{c}0.015 \\
(0.028)\end{array}$ & $\begin{array}{c}0.016 \\
(0.028)\end{array}$ & $\begin{array}{c}0.016 \\
(0.028)\end{array}$ \\
\hline$\Delta \log \left(1+\right.$ Tariff $\left.^{\text {U.S. }}\right)$ & & & $0.541^{* *}$ & $0.559^{* *}$ & $0.489^{* *}$ & $0.513^{* *}$ & $0.406^{*}$ \\
\hline$\times D_{i}^{\text {exp, U.S.-dominant }}$ & & & $(0.249)$ & $(0.247)$ & $(0.243)$ & $(0.238)$ & $(0.239)$ \\
\hline$\Delta \log \left(1+\right.$ Tariff $\left.^{\mathrm{CHN}}\right)$ & & & 0.350 & 0.335 & 0.421 & -0.462 & -0.371 \\
\hline$\times D_{i}^{\mathrm{imp}, \text { U.S.-dominant }}$ & & & (1.899) & $(1.858)$ & $(1.139)$ & $(1.122)$ & $(1.108)$ \\
\hline Firm Characteristics & Yes & Yes & Yes & Yes & Yes & Yes & Yes \\
\hline Region FE & Yes & Yes & Yes & Yes & Yes & Yes & Yes \\
\hline Industry FE & Yes & Yes & Yes & Yes & Yes & Yes & Yes \\
\hline Observations & 2,135 & 2,135 & 2,135 & 2,135 & 2,135 & 2,135 & 2,135 \\
\hline R-squared & 0.081 & 0.083 & 0.083 & 0.086 & 0.085 & 0.085 & 0.085 \\
\hline
\end{tabular}

Notes: The dependent variable is the change in firm-level trade policy uncertainty between 2017Q4 and 2018Q4. Tariff U.S. denotes the firm-level measure of exposure to U.S. tariffs on imports from China, computed as a weighted average across each firm's set of products exported to the U.S. Tariff ${ }^{\mathrm{CHN}}$ denotes the firm-level measure of tariff to Chinese tariffs on imports from the U.S., computed as a weighted average across each firm's set of products imported from the U.S. $\Delta \log \left(1+\operatorname{Tariff}^{\mathrm{U} . S}\right.$. $)$ and $\Delta \log \left(1+\operatorname{Tariff}^{\mathrm{CHN}}\right)$ are percent changes in Tariff ${ }^{\mathrm{U} . S}$. and Tariff ${ }^{\mathrm{CHN}}$ between 2017Q4 and 2018Q4. Firm characteristics include profit, revenue and capital and are measured in 2017Q4. Industries are defined according to the 3-digit Standard Industrial Classification (SIC). Robust standard errors are in parentheses. ${ }^{* * *} \mathrm{p}<0.01,{ }^{* *} \mathrm{p}<0.05,{ }^{*} \mathrm{p}<0.1$.

Table 7 shows the estimation results. In column (3), the impact of U.S. tariffs on firmlevel TPU is 0.541 points (1.274 standard deviations) higher for U.S. dependent exporters compared to non-U.S. dependent exporters. However, we do not find any heterogeneous impacts of U.S. dependent importers relative to non-U.S. dependent importers. In column (4), we then add interaction terms for the number of countries a firm exports to or imports from and find the results are almost unchanged. From columns from (5) to (7), we changed the threshold from $5 \%$ to $10 \%, 15 \%$, and $20 \%$, respectively. Reassuringly, our core results stand. To sum up, our findings indicate that the ability to hedge in export 
markets (row 3) may be diminished when firms have a high level of dependence on U.S. sales relative to firms are less reliant on U.S. sales (row 5), given the fixed costs of locating and entering new markets.

\section{Firm-level Impact of TPU on Economic Outcomes}

\subsection{Investment}

Next, we analyze whether heightened firm-level TPU impacts firm-level outcomes. To this end, we estimate the following regression:

$$
\log \left(\mathrm{K}_{i, t+k}\right)-\log \left(\mathrm{K}_{i, t}\right)=\alpha+\beta \Delta \mathrm{TPU}_{i}+\gamma X_{i}+\psi_{\mathrm{REG}}+\psi_{\mathrm{IND}}+\varepsilon_{i} .
$$

The dependent variable, $\log \left(\mathrm{K}_{i, t+k}\right)-\log \left(\mathrm{K}_{i, t}\right)$, measures the percent change in capital stocks for firm $i$ from $t=2017 \mathrm{Q} 4$ to $t+k$ where $t+k$ denotes a quarter after 2018Q4 (i.e., $t+k=\{18 Q 4,19 Q 1,19 Q 2,19 Q 3\})$. In this way we capture the dynamic response of capital stocks to TPU. The variable $\triangle \mathrm{TPU}_{i}$ measures the change in firm $i$ 's trade policy uncertainty between 2017Q4 and 2018Q4. We also control for firm characteristics including profit, revenue and capital in 2017Q4 $\left(X_{i}\right)$, region $\left(\psi_{\mathrm{REG}}\right)$ and industry $\left(\psi_{\mathrm{IND}}\right)$ fixed effects, as we did in Section 4.

Table 8: Investment and Trade Policy Uncertainty

\begin{tabular}{lcccc}
\hline \hline & \multicolumn{4}{c}{ Dependent Variable: $\Delta \log ($ Capital $)$} \\
& $(1)$ & $(2)$ & $(3)$ & $(4)$ \\
& $17 Q 4-18 Q 4$ & $17 Q 4-19 Q 1$ & $17 Q 4-19 Q 2$ & $17 Q 4-19 Q 3$ \\
\hline \multirow{2}{*}{$\begin{array}{lcccc}\text { Trade Policy Uncertainty } \\
\text { (17Q4-18Q4) }\end{array}$} & $-0.034^{* *}$ & $-0.034^{*}$ & $-0.040^{* *}$ & $-0.048^{* *}$ \\
& $(0.017)$ & $(0.019)$ & $(0.020)$ & $(0.024)$ \\
& & & & \\
Firm Characteristics & Yes & Yes & Yes & Yes \\
Region FE & Yes & Yes & Yes & Yes \\
Industry FE & Yes & Yes & Yes & Yes \\
Observations & 2,134 & 2,135 & 2,131 & 2,121 \\
R-squared & 0.109 & 0.113 & 0.111 & 0.113 \\
\hline \hline
\end{tabular}

Notes: $\Delta$ Trade Policy Uncertainty (2017Q4-2018Q4) is the change in firm-level trade policy uncertainty between 2017Q4 and 2018Q4. Firm characteristics include profit, revenue and capital and are measured in 2017Q4. Industries are defined according to the 3-digit Standard Industrial Classification (SIC). Robust standard errors are in parentheses. ${ }^{* *} \mathrm{p}<0.01,{ }^{* *} \mathrm{p}<0.05,{ }^{*} \mathrm{p}<0.1$.

Table 8 reports the estimation results. The coefficient in column (1) reflects the contemporaneous impact of changes in trade policy uncertainty on changes in capital stock during 2017Q4 - 2018Q4. In the second column, the coefficient of -0.034 is negative and 
statistically significant, and its magnitude implies that a one standard deviation increase in 2017Q4 - 2018Q4 trade policy uncertainty is associated with a cumulative 1.44 percent decrease in firm-level capital stocks in 2019Q1 compared with 2017Q4. We also report the overall effect of 2017Q4 - 2018Q4 TPU change on capital in 2019Q2 and Q3 in columns (3) and (4). In general, the (negative) magnitudes become larger as time goes by. In 2019Q3, the coefficient $\beta$ is -0.048 (i.e., a one standard deviation increase in trade policy uncertainty is associated with 2.04 percent decrease in firm-level capital stocks overall in 2019Q3). This finding is consistent with Caldara et al. (2019), who find that the negative impact of trade policy on business investment in the U.S. is statistically significant after two quarters. Likewise, heightened trade policy uncertainty, which originated from the 2018-2019 trade war, discourages firm-level investment and its impact becomes larger over longer time horizons in China.

\subsection{R\&D Expenditures}

We also explore whether TPU affects firm-level R\&D expenditures. Since the firm-level $R \& D$ expenditure variable is only available yearly, we use the percentage change in R\&D between 2017 and 2018 as a dependent variable as follows:

$$
\Delta \log (\mathrm{R} \& \mathrm{D})_{i}=\alpha+\beta \Delta \mathrm{TPU}_{i}+\gamma X_{i}+\psi_{\mathrm{REG}}+\psi_{\mathrm{IND}}+\varepsilon_{i}
$$

where $\Delta \mathrm{TPU}_{i}$ is the change in trade policy uncertainty between 2017Q4 and 2018Q4.

Table 9: R\&D Expenditures and Trade Policy Uncertainty

\begin{tabular}{|c|c|c|c|c|c|c|}
\hline & \multicolumn{6}{|c|}{ Dependent Variable: $\Delta \log (\mathrm{R} \& \mathrm{D})(2017-2018)$} \\
\hline & $(1)$ & $(2)$ & (3) & (4) & (5) & $(6)$ \\
\hline $\begin{array}{l}\Delta \text { Trade Policy Uncertainty } \\
(17 Q 4-18 Q 4)\end{array}$ & $\begin{array}{l}-0.039 \\
(0.028)\end{array}$ & $\begin{array}{l}-0.034 \\
(0.027)\end{array}$ & $\begin{array}{l}-0.048^{*} \\
(0.025)\end{array}$ & $\begin{array}{l}-0.052^{*} \\
(0.030)\end{array}$ & $\begin{array}{l}-0.049^{*} \\
(0.028)\end{array}$ & $\begin{array}{l}-0.063^{* *} \\
(0.025)\end{array}$ \\
\hline $\log (\mathrm{R} \& D)_{2017}$ & & $\begin{array}{c}-0.130^{* * *} \\
(0.030)\end{array}$ & $\begin{array}{c}-0.254^{* * *} \\
(0.053)\end{array}$ & & $\begin{array}{c}-0.150^{* * *} \\
(0.033)\end{array}$ & $\begin{array}{c}-0.326^{* * *} \\
(0.058)\end{array}$ \\
\hline Firm Characteristics & No & No & Yes & No & No & Yes \\
\hline Region FE & Yes & Yes & Yes & Yes & Yes & Yes \\
\hline Industry FE & No & No & No & Yes & Yes & Yes \\
\hline Observations & 2,032 & 2,032 & 2,004 & 2,019 & 2,019 & 1,993 \\
\hline R-squared & 0.019 & 0.083 & 0.160 & 0.069 & 0.145 & 0.260 \\
\hline
\end{tabular}

Notes: $\Delta \log (R \& D)(2017-2018)$ is the log change in firm-level R\&D expenditure between 2017 and 2018. $\Delta$ Trade Policy Uncertainty (2017Q4-2018Q4) is the change in firm-level trade policy uncertainty between 2017Q4 and 2018Q4. Firm characteristics include profit, revenue and capital and are measured in 2017Q4. Industries are defined according to the 3-digit Standard Industrial Classification (SIC). Robust standard errors are in parentheses. ${ }^{* * *} \mathrm{p}<0.01,{ }^{* *} \mathrm{p}<0.05,{ }^{*} \mathrm{p}<0.1$. 
Table 9 shows the estimation results. In columns (1) to (3), we include region fixed effects. In column (1), we start by relating the percent change in R\&D expenditure to the change in trade policy uncertainty and find that the coefficient is negative but statistically insignificant. Then, we add pre-period R\&D expenditure in column (2) and control for both pre-period R\&D expenditure and firm characteristics in column (3). In column (3), with the full set of controls, we find that the coefficient is negative and statistically significant. Finally, we add both region and industry fixed effects into the regression in column (4) and (6). In column (6), the coefficient is -0.063 and statistically significant. Quantitatively, a one standard deviation increase in trade policy uncertainty is associated with 2.68 percent decrease in $R \& D$ expenditure.

\subsection{Profits}

Next, we analyze whether heightened firm-level TPU affects firm-level profits. We specify the following regression:

$$
\Pi_{i, t+k}-\Pi_{i, t}=\alpha+\beta \Delta \mathrm{TPU}_{i}+\gamma X_{i}+\psi_{\mathrm{REG}}+\psi_{\mathrm{IND}}+\varepsilon_{i}
$$

where the dependent variable, $\Pi_{i, t+k}-\Pi_{i, t}$, measures the change in profit for firm $i$ from 2017Q4 to $t+k$ where $t+k$ denotes a quarter after 2018Q4 (i.e., $t+k=\{18 Q 4,19 Q 1,19 Q 2,19 Q 3\}$ ). Note that we use the level of profits, i.e., millions of Chinese yuan, instead of the log of profits to allow for negative values.

Table 10 displays estimation results. In columns (1) and (2), which report the shortrun changes in firm profits, both coefficients are negative but statistically insignificant. The effects of profits, when measured over a slightly longer time interval, as displayed in columns (3) and (4), remain negative, but they attain statistical significance. According to estimation results, we do not detect a significant impact of 2017Q4 - 2018Q4 TPU change on firm profits at the same time horizon as displayed in column (1). As shown in column (3) and (4), the cumulative effect of 2017Q4 - 2018Q4 TPU change on profit becomes significantly negative in 2019Q2 and Q3 - a one standard deviation increase in 2017Q4 2018Q4 TPU is associated with an overall decline in profits by 8.9 and 11.7 percent later on in 2019Q2 and Q3, suggesting that it takes time for profits to erode and give way to losses. ${ }^{31}$

\footnotetext{
${ }^{31}$ The percent changes are calculated based on the relative magnitude as compared with listed firms' average profit, 94.24 million Chinese yuan, in 2017Q4.
} 
Table 10: Profits and Trade Policy Uncertainty

\begin{tabular}{lcccc}
\hline \hline & \multicolumn{4}{c}{ Dependent Variable: $\Delta$ Profit } \\
& 17Q4-18Q4 & 17Q4-19Q1 & 17Q4-19Q2 & 17Q4-19Q3 \\
& $(1)$ & $(2)$ & $(3)$ & $(4)$ \\
\hline \multirow{2}{*}{ Trade Policy Uncertainty } & -24.571 & -9.609 & $-19.786^{*}$ & $-25.915^{*}$ \\
$(17 Q 4-18 Q 4)$ & $(16.381)$ & $(11.278)$ & $(10.503)$ & $(13.598)$ \\
& & & & \\
Firm Characteristics & Yes & Yes & Yes & Yes \\
Region FE & Yes & Yes & Yes & Yes \\
Industry FE & Yes & Yes & Yes & Yes \\
Observations & 2,135 & 2,135 & 2,131 & 2,121 \\
R-squared & 0.142 & 0.269 & 0.191 & 0.251 \\
\hline \hline
\end{tabular}

Notes: $\Delta$ Trade Policy Uncertainty (2017Q4-2018Q4) is the change in firm-level trade policy uncertainty between 2017Q4 and 2018Q4. Firm characteristics include profit, revenue and capital and are measured in 2017Q4. Industries are defined according to the 3-digit Standard Industrial Classification (SIC). Robust standard errors are in parentheses. ${ }^{* * *} \mathrm{p}<0.01,{ }^{* *}$ $\mathrm{p}<0.05,{ }^{*} \mathrm{p}<0.1$.

\subsection{The Direct Impacts of Tariffs on Economic Outcomes}

We have shown how heightened firm-level trade policy uncertainty during the trade war leds to reductions in firm-level investment, R\&D expenditures and profits for Chinese listed firms. However, our results may be capturing instead how rising U.S. tariffs and Chinese retaliatory tariffs have negatively affected Chinese firms directly, by reducing demand for Chinese exports or by increasing the cost of imported inputs. For this reason, it is important to validate that the trade policy uncertainty channel effects on firm operational outcomes is present when the direct impacts of tariffs is included. To this end, we augment our baseline equations (4) and (5) with U.S. and Chinese tariff exposure measures as follows:

$$
\begin{aligned}
\log \left(\mathrm{K}_{i, t+k}\right)-\log \left(\mathrm{K}_{i, t}\right) & =\alpha+\beta_{1} \Delta \mathrm{TPU}_{i}+\beta_{2} \Delta \log \left(1+\operatorname{Tariff}_{i}^{\mathrm{USS} .}\right)+\beta_{3} \Delta \log \left(1+\operatorname{Tariff}_{i}^{\mathrm{CHN}}\right) \\
& +\gamma X_{i}+\psi_{\mathrm{REG}}+\psi_{\mathrm{IND}}+\varepsilon_{i} \\
\Pi_{i, t+k}-\Pi_{i, t} & =\alpha+\beta_{1} \Delta \mathrm{TPU}_{i}+\beta_{2} \Delta \log \left(1+\operatorname{Tariff}_{i}^{\mathrm{USS}}\right)+\beta_{3} \Delta \log \left(1+\operatorname{Tariff}_{i}^{\mathrm{CHN}}\right) \\
& +\gamma X_{i}+\psi_{\mathrm{REG}}+\psi_{\mathrm{IND}}+\varepsilon_{i}
\end{aligned}
$$

where $\beta_{1}$ measures the trade policy uncertainty effect while the coefficients $\beta_{2}$ and $\beta_{3}$ capture the direct impacts of tariffs.

Tables 11 and 12 report the estimation results. Reassuringly, the sign and significance of the coefficients of the trade policy uncertainty effect on investment and profits remain unchanged, even after controlling for the direct impact of tariffs. Notably, the direct impacts of U.S. and Chinese tariff exposure measures on both investment and profit are 
statistically insignificant.

Table 11: Investment, Trade Policy Uncertainty, and Tariffs

\begin{tabular}{|c|c|c|c|c|}
\hline & \multicolumn{4}{|c|}{ Dependent Variable: $\Delta \log ($ Capital $)$} \\
\hline & $\begin{array}{c}\text { 17Q4-18Q4 } \\
(1)\end{array}$ & $\begin{array}{c}\text { 17Q4-19Q1 } \\
(2)\end{array}$ & $\begin{array}{c}\text { 17Q4-19Q2 } \\
(3)\end{array}$ & $\begin{array}{c}\text { 17Q4-19Q3 } \\
(4)\end{array}$ \\
\hline $\begin{array}{l}\Delta \text { Trade Policy Uncertainty } \\
(17 Q 4-18 Q 4)\end{array}$ & $\begin{array}{l}-0.036^{* *} \\
(0.017)\end{array}$ & $\begin{array}{l}-0.035^{*} \\
(0.019)\end{array}$ & $\begin{array}{l}-0.042^{* *} \\
(0.020)\end{array}$ & $\begin{array}{l}-0.050^{* *} \\
(0.025)\end{array}$ \\
\hline$\Delta \log (1+$ Tariff U.S. $)$ & 0.090 & 0.054 & 0.111 & 0.163 \\
\hline$(17 Q 4-18 Q 4)$ & $(0.086)$ & $(0.093)$ & $(0.100)$ & $(0.114)$ \\
\hline$\Delta \log \left(1+\right.$ Tariff $\left.^{\mathrm{CHN}}\right)$ & 0.176 & 0.161 & 0.196 & 0.237 \\
\hline$(17 Q 4-18 Q 4)$ & $(0.163)$ & $(0.175)$ & $(0.190)$ & $(0.208)$ \\
\hline Firm Characteristics & Yes & Yes & Yes & Yes \\
\hline Region FE & Yes & Yes & Yes & Yes \\
\hline Industry FE & Yes & Yes & Yes & Yes \\
\hline Observations & 2,134 & 2,135 & 2,131 & 2,121 \\
\hline R-squared & 0.110 & 0.113 & 0.112 & 0.115 \\
\hline
\end{tabular}

Notes: $\Delta$ Trade Policy Uncertainty (2017Q4-2018Q4) is the change in firm-level trade policy uncertainty between 2017Q4 and 2018Q4. Firm characteristics include profit, revenue and capital and are measured in 2017Q4. Industries are defined according to the 3-digit Standard Industrial Classification (SIC). Robust standard errors are in parentheses. ${ }^{* * *} \mathrm{p}<0.01,{ }^{* *}$ $\mathrm{p}<0.05,{ }^{*} \mathrm{p}<0.1$.

Discussion There may be several factors that could explain the absence of direct tariff impacts in these new results. First, the average ratio of exports to the U.S. to total sales for Chinese listed firms in the sample is about 1.7 percent in 2016 according to Chinese customs data and COMPUSTAT Global data. ${ }^{32}$ The low ratio suggests that the output loss resulting from rising U.S. tariffs would be quite limited even if U.S. tariffs in a firm's industry have risen substantially. Correspondingly, reactions in investment and profits would be small for these firms. ${ }^{33}$

\footnotetext{
${ }^{32}$ The calculation is based on the COMPUSTAT sample restricted to the manufacturing sector. The average ratio of exports to the U.S. is computed as U.S. exports relative to total sales that include domestic sales. As not all manufacturing firms are exporters, we set exports of the non-exporting firms as zero in the above calculation.

${ }^{33}$ Firm shares of imports from the U.S. are also small, possibly leading to the null effect of rising retaliatory tariffs. In Appendix C, we further investigate it by adding interaction terms. The exercise seeks to explore whether the direct impact of U.S. and Chinese tariff exposures are stronger for firms that export to and/or import from the U.S. more. Results are reported in Appendix Tables C.1 and C.2. The coefficient of the interaction of U.S. tariffs and U.S. export shares is insignificant, while the interaction between Chinese tariffs and U.S. import shares is significantly negative. Though the overall direct impact of Chinese retaliatory tariffs is insignificant, Chinese firms that concentrate their imports in the U.S. suffer from the trade war, suggesting that import sourcing is probably less flexible for critical parts embedded in the ongoing relationship between Chinese firms and U.S. exporters.
} 
Table 12: Profit, Trade Policy Uncertainty, and Tariffs

\begin{tabular}{|c|c|c|c|c|}
\hline & \multicolumn{4}{|c|}{ Dependent Variable: $\Delta$ Profit } \\
\hline & $\begin{array}{c}\text { 17Q4-18Q4 } \\
(1)\end{array}$ & $\begin{array}{c}\text { 17Q4-19Q1 } \\
(2)\end{array}$ & $\begin{array}{c}\text { 17Q4-19Q2 } \\
\text { (3) }\end{array}$ & $\begin{array}{c}\text { 17Q4-19Q3 } \\
(4)\end{array}$ \\
\hline $\begin{array}{l}\Delta \text { Trade Policy Uncertainty } \\
(17 Q 4-18 Q 4)\end{array}$ & $\begin{array}{l}-26.079 \\
(16.391)\end{array}$ & $\begin{array}{c}-8.624 \\
(11.352)\end{array}$ & $\begin{array}{l}-18.182^{*} \\
(10.597)\end{array}$ & $\begin{array}{l}-25.154^{*} \\
(13.807)\end{array}$ \\
\hline $\begin{array}{l}\Delta \log (1+\text { Tariff } \mathrm{U.S.}) \\
(17 \mathrm{Q} 4-18 \mathrm{Q} 4)\end{array}$ & $\begin{array}{c}102.150 \\
(122.952)\end{array}$ & $\begin{array}{l}-38.250 \\
(79.449)\end{array}$ & $\begin{array}{l}-93.622 \\
(86.981)\end{array}$ & $\begin{array}{l}-4.881 \\
(79.447)\end{array}$ \\
\hline $\begin{array}{l}\Delta \log \left(1+\text {Tariff}^{\mathrm{CHN}}\right) \\
(17 \mathrm{Q} 4-18 \mathrm{Q} 4)\end{array}$ & $\begin{array}{l}194.837 \\
(211.802)\end{array}$ & $\begin{array}{l}-159.796 \\
(147.866)\end{array}$ & $\begin{array}{l}-221.017 \\
(188.854)\end{array}$ & $\begin{array}{l}-145.197 \\
(158.522)\end{array}$ \\
\hline Firm Characteristics & Yes & Yes & Yes & Yes \\
\hline Region FE & Yes & Yes & Yes & Yes \\
\hline Industry FE & Yes & Yes & Yes & Yes \\
\hline Observations & 2,135 & 2,135 & 2,131 & 2,121 \\
\hline R-squared & 0.143 & 0.270 & 0.191 & 0.252 \\
\hline
\end{tabular}

Notes: $\Delta$ Trade Policy Uncertainty (2017Q4-2018Q4) is the change in firm-level trade policy uncertainty between 2017Q4 and 2018Q4. Firm characteristics include profit, revenue and capital and are measured in 2017Q4. Industries are defined according to the 3-digit Standard Industrial Classification (SIC). Robust standard errors are in parentheses. ${ }^{* * *} \mathrm{p}<0.01,{ }^{* *}$ $\mathrm{p}<0.05,{ }^{*} \mathrm{p}<0.1$.

A second explanation is that a third country may have been chosen by Chinese exporters to re-route exports. Liu and Shi (2019) find that trade re-routing has been used by Chinese firms in the past to avoid antidumping duties. ${ }^{34}$ Though we cannot formally test firm re-routing behaviors because of data limitations, the recent news report by Chau and Boudreau (2019) suggests that there is a high possibility that some re-routing took place during the U.S.-China trade war. According to the report, exports from Vietnam to the U.S. have grown strongly in 2019 and many products such as plywood are produced in China might be shipped to the U.S. with 'Made in Vietnam' labels.

Third, trade diversification can help mitigate the negative impacts of tariffs. For instance, if Chinese firms easily switch buyers, then the direct negative impacts of tariffs on firm-level investment and profits would be reduced. ${ }^{35}$ In fact, the Chinese government has implemented policies to help affected Chinese producers to switch to other partners. ${ }^{36}$

\footnotetext{
${ }^{34}$ Trade re-routing means firms send their products to a third country where U.S. tariffs are not applicable. After that, goods are reissued certificates of origin and sent to the final destination country without being subject to the U.S. tariffs.

${ }^{35}$ Our previous analysis has uncovered a real hedging channel where Chinese exporters that are more diversified in terms of destination markets see a lower increase in trade policy uncertainty.

${ }^{36}$ According to the report by $\mathrm{CNBC}$, the Chinese government has taken mainly four ways to bolster business during the trade war, which includes increasing government support, opening channels to other international markets through programs such as free trade zones and the Belt and Road Initiative, improving the environment for state-owned and foreign enterprises and implementing policies such as tax and fee cuts. See https://www.cnbc.com/2019/08/26/
} 
Lastly, as firms in the sample are large by nature and may engage in a variety of business activities other than trade-oriented ones, firms may have adapted necessary operation change in response to future tariff increase (e.g., switching from the trade-oriented business to non-trade-oriented ones), leading to a limited direct impact of tariffs. This is in line with the finding that even tariff-induced TPU change does not significantly affect a firm's total revenue that may consist of sales generated by non-trade-oriented business activities. On the contrary, it is less controversial that the rising TPU makes firms less certain of what to plan for the future, leading them to postpone investment (Handley et al. (2020)), and it is exactly as what we find in the data. ${ }^{37}$

Nonetheless, the stylized facts highlighted by this paper contribute to the understanding on how firms respond to rising trade policy uncertainty, which can be used later as models of dynamic endogenous effects of TPU are developed.

\subsection{Robustness Checks}

To the extent that some Chinese firms are focused on serving the domestic market, while others are more heavily involved in exporting, we explore if our main results change according to firm orientation. For this purpose, we focus on subsets of firms based on indicator variables $\mathbb{1}$ (Persistent Exporter) ( $\mathbb{1}$ (Persistent Importer)) that equal one if the firm exported (imported) in all years between 2013 and 2016. Alternatively, orientation could be defined via the measure of exports-to-revenue or imports-to-cost ratio. Table D.1 reports the result under both specifications. The impact of tariffs on firm TPU remains similar to that in Table 3 among both groups. In particular, we observe that the increase in firm TPU is more pronounced among exporters. We further include those firm orientation variables in regressions investigating the role of trade diversification, reporting the results in Table D.2. We continue to find that firms exporting to a larger number of destinations experienced smaller increases in TPU.

As suggested by Table 6, firms with a more diversified set of trade relationships experienced smaller increases in TPU. However, this outcome might also be shaped by differences in firm financial positions. If it possible that more diversified firms may have better access to funds and that the access to funds, rather than the diversification, may help these firms to adapt to the changing environment. To address this concern, we follow

trade-war-what-it-means-for-china-firms-as-trumps-calls-us-firms-to-go.html for details. In addition to the above discussion, Cavallo et al. (2019) also find that imports of U.S. retailers increased after the initial announcement of possible tariffs, but before the full implementation of tariffs. Therefore, by completing sales/purchases beforehand, the impact of tariffs on firm sales for Chinese firms can be very limited overall.

${ }^{37}$ By modeling firm's dynamic sourcing decision, Handley et al. (2020) show that firms tend to postpone making investment decision in the presence of trade policy uncertainty. 
Manova and Yu (2016) and construct firm-level financial measures as follows:

$$
\text { Liquidity }=\frac{\text { Current assets-Current liabilities }}{\text { Total assets }}, \quad \text { Leverage }=\frac{\text { Current liabilities }}{\text { Current assets }} .
$$

We interact the financial terms with tariffs in our new regression specification. This allows us to determine whether firms that were in a better financial position experienced a lower increases in TPU in response to increases in tariffs. In Appendix Table D.3, both interaction terms are statistically insignificant. Hence, the results confirm that firm liquidity and leverage do not mediate the impact of tariffs on TPU during the trade war.

\section{Conclusions}

In this paper, we explore the sources and consequences of trade-policy uncertainty during the ongoing U.S.-China trade war. Our analysis is based on a novel measure of firmlevel TPU constructed from a textual analysis of firm-level statements, and firm-specific measures of exposure to trade war tariffs based on customs data and tariff lines. The firm-level TPU measure accurately tracks existing aggregate indices of TPU in China, and reveals a dramatic TPU spike during the trade war.

Our first contribution is to open the TPU black box. While it has been generally acknowledged that TPU must have played a role in the trade war (IMF, 2018), there is little understanding of how the process works, the magnitude of this channel, and which firms are most exposed to it. We move one step in this direction and take advantage of the variation across Chinese firms in their exposure to the trade war. We show that firm-level increases in TPU experienced during this period are systematically associated with firmlevel exposure to both U.S. tariffs (which lower U.S. demand for Chinese exports) and Chinese tariffs (which raise the cost of imported inputs for Chinese firms). We further show that the impact of tariffs on TPU is heterogeneous across firm characteristics, as the tariff effect on TPU is largest for smaller and less diversified firms.

The second contribution of our paper is to document the negative consequences of the TPU spike on firm investment, R\&D expenditures and profits. Our work allows us to identify the timing of TPU effects, including the changes over the short- to medium-run. The effect exists, and is quantitatively important, after controlling for the direct impact of tariffs on all these outcomes. We find that a one standard deviation increase in TPU leads to a reduction in investment, R\&D expenditures, and profits by $1.4,2.7$, and $8.9 \%$, respectively.

Overall, our work highlights the importance of the TPU channel during the ongoing U.S.-China trade war; the paper also illustrates the benefits of new measures of firm- 
level uncertainty based on textual analysis of firm statements (Hassan et al., 2020, 2019; Caldara et al., 2019). The documented stylized facts contribute to understanding how firms respond to rising trade policy uncertainty, which can be used later as models of dynamic endogenous effects of TPU are developed. 


\section{References}

Alessandria, George A, Shafaat Y Khan, and Armen Khederlarian, "Taking Stock of Trade Policy Uncertainty: Evidence from China's Pre-WTO Accession," NBER Working Paper \#25965, 2019.

Amiti, Mary, Sang Hoon Kong, and David Weinstein, "The Effect of the US-China Trade War on US Investment," NBER Working Paper \#27114, 2020.

_ , Stephen J Redding, and David Weinstein, "The Impact of the 2018 Trade War on US Prices and Welfare," NBER Working Paper \#25672, 2019.

Autor, David, David Dorn, Gordon Hanson, Gary Pisano, and Pian Shu, "Foreign Competition and Domestic Innovation: Evidence from US Patents," American Economic Review: Insights, 2020, forthcoming.

Baker, Scott R, Nicholas Bloom, and Steven J Davis, "Measuring economic policy uncertainty," The Quarterly Journal of Economics, 2016, 131 (4), 1593-1636.

Ball, Ray, "International Financial Reporting Standards (IFRS): pros and cons for investors," Accounting and Business Research, 2006, 36 (sup1), 5-27.

Barth, Mary E, Wayne R Landsman, and Mark H Lang, "International accounting standards and accounting quality," Journal of Accounting Research, 2008, 46 (3), 467-498.

Benguria, Felipe, "The Global Impact of the US-China Trade War: Firm-Level Evidence," SSRN Working Paper, 2019.

_ and Felipe Saffie, "Dissecting the Impact of the 2018-2019 Trade War on US Exports," Available at SSRN, 2019.

Bloom, Nicholas, Kyle Handley, André Kurmann, and Philip Luck, "The Impact of Chinese Trade on US Employment: The Good, The Bad, and The Apocryphal," in "American Economic Association Annual Meetings" 2019.

Bown, Chad and Melina Kolb, "Trump's Trade War Timeline: An Up-To-Date Guide," Peterson Institute for International Economics, 2019, May.

Brandt, Loren, Johannes Van Biesebroeck, Luhang Wang, and Yifan Zhang, “WTO Accession and Performance of Chinese Manufacturing Firms," American Economic Review, 2017, 107 (9), 2784-2820. 
Caldara, Dario, Matteo Iacoviello, Patrick Molligo, Andrea Prestipino, and Andrea Raffo, "The economic effects of trade policy uncertainty," Journal of Monetary Economics, 2019.

Carballo, Jeronimo, Kyle Handley, and Nuno Limão, "Economic and policy uncertainty: Export dynamics and the value of agreements," NBER Working Paper \#24368, 2018.

Caselli, Francesco, Miklós Koren, Milan Lisicky, and Silvana Tenreyro, "Diversification through trade," The Quarterly Journal of Economics, 2020, 135 (1), 449-502.

Cavallo, Alberto, Gita Gopinath, Brent Neiman, and Jenny Tang, "Tariff passthrough at the border and at the store: evidence from US trade policy," NBER Working Paper \#26396, 2019.

Chau, Mai Ngoc and John Boudreau, "Chinese Exporters Dodge Tariffs With Fake Madein-Vietnam Labels," Bloomberg, 2019.

Chen, Jean Jinghan and Haitao Zhang, "The impact of regulatory enforcement and audit upon IFRS compliance-Evidence from China," European Accounting Review, 2010, 19 (4), 665-692.

Chen, Wei, Xilu Chen, Chang-Tai Hsieh, and Zheng Song, "A Forensic Examination of China's National Accounts," NBER Working Paper \#25754, 2019.

Chen, Xiao, Chi-Wen Jevons Lee, and Jing Li, "Government assisted earnings management in China," Journal of Accounting and Public Policy, 2008, 27 (3), 262-274.

CSRC, Annual Report: China Securities Regulatory Commission, Beijing: China Financial and Economic Publishing House, 2008.

Daske, Holger, Luzi Hail, Christian Leuz, and Rodrigo Verdi, "Mandatory IFRS reporting around the world: Early evidence on the economic consequences," Journal of Accounting Research, 2008, 46 (5), 1085-1142.

Davis, Steven J, Dingquian Liu, and Xuguang Simon Sheng, "Economic Policy Uncertainty in China Since 1946: The View from Mainland Newspapers," Technical Report, Working paper, August 2019.

Fajgelbaum, Pablo D, Pinelopi K Goldberg, Patrick J Kennedy, and Amit K Khandelwal, "The Return to Protectionism," NBER Working Paper \#25638, 2019. 
Fan, Haichao, Yao Amber Li, and Stephen R Yeaple, "On the relationship between quality and productivity: Evidence from China's accession to the WTO," Journal of International Economics, 2018, 110, 28-49.

Fan, Joseph, Randall Morck, and Bernard Yeung, "Capitalizing China," NBER Working Paper \#17687, 2011.

Feng, Ling, Zhiyuan Li, and Deborah L Swenson, "Trade Policy Uncertainty and Exports: Evidence from China's WTO Accession," Journal of International Economics, 2017, 106, 20-36.

Graziano, Alejandro, Kyle Handley, and Nuno Limão, "Brexit uncertainty and trade disintegration," NBER Working Paper \#25334, 2018.

Guadalupe, Maria and Julie Wulf, "The Flattening Firm and Product Market Competition: The Effect of Trade Liberalization on Corporate Hierarchies," American Economic Journal: Applied Economics, 2010, 2 (4), 105-27.

Handley, Kyle, "Exporting under trade policy uncertainty: Theory and evidence," Journal of international Economics, 2014, 94 (1), 50-66.

- and J Frank Li, "Measuring the effects of firm uncertainty on economic activity: New evidence from one million documents," University of Michigan, 2018.

- and Nuno Limao, "Trade and investment under policy uncertainty: theory and firm evidence," American Economic Journal: Economic Policy, 2015, 7 (4), 189-222.

- and Nuno Limão, "Policy Uncertainty, Trade, and Welfare: Theory and Evidence for China and the United States," American Economic Review, 2017, 107 (9), 2731-83.

_, Nuno Limao, Rodney Ludema, and Zhi Yu, "Firm Input Choice Under Trade Policy Uncertainty," Technical Report, Working paper 2020.

Hassan, Tarek A, Stephan Hollander, Laurence van Lent, and Ahmed Tahoun, "Firmlevel political risk: Measurement and effects," The Quarterly Journal of Economics, 2019, 134 (4), 2135-2202.

Hassan, Tarek Alexander, Stephan Hollander, Laurence van Lent, and Ahmed Tahoun, “The Global Impact of Brexit Uncertainty,” NBER Working Paper \#26609, 2020.

Hombert, Johan and Adrien Matray, "Can Innovation Help US Manufacturing Firms Escape Import Competition from China?," The Journal of Finance, 2018, 73 (5), 20032039. 
Huang, Yi, Chen Lin, Sibo Liu, and Heiwai Tang, "Trade Linkages and Firm Value: Evidence from the 2018 US-China Trade War," SSRN Working Paper, 2018.

IASB, Measurement Bases for Financial Accounting: Measurement on Initial Recognition. Discussion Paper [condensed Version]., International Accounting Standards Board, 2005.

_, International Financial Reporting Standards (IFRS's): Including International Accounting Standards (IAS's) and Interpretations as at..., International Accounting Standards Board, 2006.

IMF, “IMF World Economic Outlook,” 2018, Oct.

Jermakowicz, Eva K, Jenice Prather-Kinsey, and Inge Wulf, "The value relevance of accounting income reported by DAX-30 German companies," Journal of International Financial Management \& Accounting, 2007, 18 (3), 151-191.

Keller, Wolfgang and Stephen R Yeaple, "Multinational Enterprises, International Trade, and Productivity Growth: Firm-Level Evidence from the United States," The Review of Economics and Statistics, 2009, 91 (4), 821-831.

Khandelwal, Amit K, Peter K Schott, and Shang-Jin Wei, "Trade Liberalization and Embedded Institutional Reform: Evidence from Chinese Exporters," American Economic Review, 2013, 103 (6), 2169-95.

Kramarz, Francis, Julien Martin, and Isabelle Mejean, "Volatility in the small and in the large: The lack of diversification in international trade," Journal of International Economics, 2020, 122, 103276.

Li, M, “CARD Trade War Tariffs Database,” 2018.

Liu, Chunhui, Lee J Yao, Nan Hu, and Ling Liu, "The impact of IFRS on accounting quality in a regulated market: An empirical study of China," Journal of Accounting, Auditing \& Finance, 2011, 26 (4), 659-676.

Liu, Xuepeng and Huimin Shi, "Anti-dumping duty circumvention through trade rerouting: Evidence from Chinese exporters," The World Economy, 2019, 42 (5), 14271466.

Lu, Yi and Linhui Yu, "Trade Liberalization and Markup Dispersion: Evidence from China's WTO Accession," American Economic Journal: Applied Economics, 2015, 7 (4), 221-53. 
Macedoni, Luca and Mingzhi Jimmy Xu, "Flexibility and productivity: Towards the understanding of firm heterogeneity for multi-product exporters," Technical Report, Working Paper 2018.

Manova, Kalina and Zhihong Yu, "How firms export: Processing vs. ordinary trade with financial frictions," Journal of International Economics, 2016, 100, 120-137.

Peng, Songlan and Joyce Smith, "Chinese GAAP and IFRS: An analysis of the convergence process," Journal of International Accounting, Auditing and Taxation, 2010, 19 (1), $16-34$.

_, Rasoul H Tondkar, Joyce van der Laan Smith, and David W Harless, "Does convergence of accounting standards lead to the convergence of accounting practices?: A study from China," The International Journal of Accounting, 2008, 43 (4), 448-468.

Pierce, Justin R and Peter K Schott, "The Surprisingly Swift Decline of US Manufacturing Employment," American Economic Review, 2016, 106 (7), 1632-62.

Rodriguez-Lopez, Antonio and Miaojie Yu, "All-Around Table Liberalization and FirmLevel Employment: Theory and Evidence from China," Technical Report, CESifo Working Paper Series 2017.

Steinberg, Joseph B, "Brexit and the macroeconomic impact of trade policy uncertainty," Journal of International Economics, 2019, 117, 175-195.

_ , "Comment on:"The economic effects of Trade Policy Uncertainty" by Dario Caldara, Matteo Iacoviello, Patrick Molligo, Andrea Prestipino, and Andrea Raffo," Journal of Monetary Economics, 2020, 109, 60-64.

Street, Donna L and Sidney J Gray, "Factors influencing the extent of corporate compliance with International Accounting Standards: summary of a research monograph," Journal of International Accounting, Auditing and Taxation, 2002, 11 (1), 51-76.

Topalova, Petia and Amit Khandelwal, "Trade liberalization and firm productivity: The case of India," Review of Economics and Statistics, 2011, 93 (3), 995-1009.

Xiang, Bing, "Institutional factors influencing China's accounting reforms and standards," Accounting Horizons, 1998, 12 (2), 105. 